\title{
Plant-Derived Leading Compounds for Chemotherapy of Human Immunodefiency Virus (HIV) Infection - An Update (1998 - 2007)
}

\author{
Author \\ Paul $\operatorname{Cos}^{1}$, Louis Maes ${ }^{1,2}$, Arnold Vlietinck ${ }^{3}$, Luc Pieters ${ }^{3}$ \\ Affiliation \\ Laboratory of Microbiology, Parasitology and Hygiene (LMPH), Department of Pharmaceutical Sciences, \\ University of Antwerp, Belgium \\ Institute of Tropical Medicine, Antwerp, Belgium \\ Laboratory of Pharmacognosy and Pharmaceutical Analysis, Department of Pharmaceutical Sciences, \\ University of Antwerp, Belgium
}

Key words

- HIV

- antiviral activity

plant-derived products

- natural products

- anti-HIV properties

- anti-AIDS products received April 5, 2008

revised June 2, 2008

accepted June 6, 2008

\section{Bibliography}

DOI $10.1055 / \mathrm{s}-2008-1081314$ Planta Med 2008; 74: 1323-

1337

(c) Georg Thieme Verlag KG

Stuttgart · New York

Published online July 31, 2008

ISSN 0032-0943

\section{Correspondence}

Prof. Dr. Paul Cos

Laboratory of Microbiology,

Parasitology and Hygiene (LMPH)

Department of Pharmaceutical Sciences

University of Antwerp

Groenenborgerlaan 171

2020 Antwerp

Belgium

Tel.: +32-3-265-3217

paul.cos@ua.ac.be

\section{Abstract}

$\nabla$

The high number of citations of the previous review on anti-HIV compounds from plants published in 1998 in Planta Medica indicates the importance of natural products research in the battle against HIV. Therefore, we have decided to write an update of our previous review paper, this time covering the time span 1998-2007.
The following antiviral chemical classes are discussed in detail: alkaloids, carbohydrates, coumarins, flavonoids, lignans, phenolics, proteins, quinones/xanthones, tannins and terpenes. If available, chemical structures, antiviral activity and selectivity, mechanism of action, and structure-activity relationship are presented.

\section{Introduction \\ $\nabla$}

Almost ten years have passed since our first review "Plant-Derived Leading Compounds for Chemotherapy of Human Immunodefiency Virus (HIV) Infection" [1]. Much research effort has focused on the prevention and therapy of this infection resulting in AIDS, and despite considerable progress being made, still no vaccine that prevents infection or therapy that cures the disease and eliminates all infectious particles is yet available. Nevertheless, research efforts have been tremendous and a keyword search on "HIV" in the ISI Web of Knowledge ${ }^{S M}$ yielded at this time almost 90,000 published papers in the time frame 1998 - 2007. In addition to biotechnological techniques, molecular modelling, etc., exploitation of natural resources to find new lead compounds against HIV is still a valuable approach. In Planta Medica alone, more than 40 papers on HIV have been published since 1998, including a review paper on HIV reverse transcriptase inhibitors of natural origin [2]. The high number of citations of the previous review on anti-HIV compounds from plants published in 1998 in Planta Medica indicates the importance of natural products research in the battle against HIV. Therefore, we decided to write an update of our previous review paper, this time covering the time span 1998-2007. Part of this material was also included in our review paper published in 2003 on plant substances as antiviral agents, focusing on HIV as well as other viruses, covering the period 1997-2001 [3], and in our review published in 2004 focusing on mechanisms of action of plant substances as anti-HIV agents [4].

HIV, the causative agent of AIDS, is a member of the lentivirus subfamily of retroviruses. From the two known HIV-types, HIV-1 is the most pathogenic. Antiretroviral drugs have transformed it from a rapid lethal infection into a chronic condition that can be controlled for many years through combination therapies with different classes of antiviral drugs, also known as highly active antiretroviral therapy (HAART) [5] Anti-HIV drugs are classified into different groups according to their activity on the replicative cycle of HIV, which can be roughly divided into ten different steps [6]. These are virus-cell adsorption, virus-cell fusion, uncoating, reverse transcription, integration, DNA replication, transcription, translation, budding (assembly/release), and maturation. There are currently 24 compounds approved for the treatment of HIV: a) seven nucleoside reverse transcriptase inhibitors or NRTIs (zidovudine or AZT, didanosine or ddI, zalcitabine or ddC, stavudine or d4T, lamivudine or 3TC, abacavir or ABC, and emtricitabine); b) one nucleotide reverse transcriptase inhibitor (tenofovir disoproxil fumarate); c) four non-nucleoside reverse transcriptase inhibitors or NNRTIs (nevirapine, delavirdine, efavirenz, and 
etravirine); d) ten HIV protease inhibitors or PIs (saquinavir, ritonavir, indinavir, nelfinavir, amprenavir, lopinavir, atazanavir, fosamprenavir, tipranavir and darunavir); e) a fusion inhibitor (enfuvirtide); f) an entry inhibitor - CCR5 co-receptor antagonist (maraviroc); and g) an HIV integrase strand transfer inhibitor (raltegravir) [7]. NRTIs and NNRTIs inhibit both reverse transcriptases, but they are targeted at the substrate (dNTP) and allosteric non-substrate binding sites, respectively. PIs bind to the active site of the viral protease enzyme, preventing the processing of viral proteins into functional forms. Viral particles are still produced when the protease is inhibited, but these particles are not infectious. Integrase inhibitors block the action of integrase, i.e., an enzyme that catalyzes the integration of viral DNA into host DNA. Besides viral enzymes, the viral entry is an attractive therapeutic target for HIV. A fusion inhibitor is a synthetic peptide that blocks viral/cellular membrane fusion triggered by gp41 and thus suppresses viral proliferation, while the entry inhibitor maraviroc blocks the chemokine receptor CCR5 which HIV uses as a coreceptor to bind and enter a human helper T cell. Due to the rapid emergence of drug-resistant strains, new antiviral therapeutics which act by other mechanisms are highly desirable for the treatment of HIV infections. Taking into account the enormous number and the amazing structural diversity of the currently available plant constituents, the plant kingdom should be further explored as a source of new and diverse antiviral agents. In this review, only those compounds that have been structurally characterised and possess a significant antiviral activity will be discussed. The latter means $\mathrm{IC}_{50}$ values lower than $25 \mu \mathrm{M}$ or $\mu \mathrm{g} / \mathrm{mL}$ [8]. An intrinsic component of the antiviral testing is the determination of a selectivity index (SI) towards the supporting host cell. The SI refers to the ratio of the maximum drug concentration causing either $50 \%$ or $90 \%$ inhibition of growth of normal cells $\left(\mathrm{CC}_{50}, \mathrm{CC}_{90}\right)$ and the minimum drug concentration at which $50 \%$ or $90 \%$ of the virus is inhibited $\left(\mathrm{IC}_{50}, \mathrm{IC}_{90}\right)$. Reports of antiviral activity of extracts/compounds even at very low concentrations but without SI data are of limited value [8].

\section{Anti-HIV Plant-Derived Agents}

$\nabla$

\section{Alkaloids}

In our first review the naphthylisoquinoline alkaloid dimers, michellamines A (1), B (2) and C (3), from the tropical liana Ancistrocladus korupensis were discussed. They act in a complex manner by at least two antiviral mechanisms, inhibition of reverse transcriptase and inhibition of HIV-induced cellular fusion. In addition, the michellamines were found to inhibit rat brain protein kinase $\mathrm{C}$ with $\mathrm{IC}_{50}$ values in the $15-35 \mu \mathrm{M}$ range [9]. From the same plant michellamines D - F were obtained, exhibiting in vitro HIV inhibitory activity comparable to michellamine B [10]. Michellamine B has undergone extensive preclinical evaluation as a potential anti-AIDS drug, but has been considered too toxic for advancement to clinical trials. Therefore, synthetic efforts have been made in order to prepare less toxic and more potent derivatives. Jozimine C (4) was the synthetically prepared dimer of dioncophylline $\mathrm{C}$, showing a close structural similarity with the michellamines ( $\bullet$ Fig. 1 ). Its anti-HIV activity (HIV-1) was nearly as good as michellamine B, but it also showed a distinct cytotoxicity, limiting its therapeutic range [11]. Octadehydromichellamine (5), a fully dehydrogenated structural analogue, was the first synthetic michellamine without centrochirality. It showed some anti-HIV activity (HIV-1)
( $\mathrm{IC}_{50}=29 \mu \mathrm{M}$ ) comparable to michellamine $\mathrm{B}$, but with cytotoxicity at $\mathrm{CC}_{50}=104 \mu \mathrm{M}[12]$.

Some nitrogen-containing sugar analogues reported in our first review, such as castanospermine and 1-deoxynojirimycin, were capable of inhibiting $N$-linked oligosaccharide processing, and inhibited HIV replication [13], [14]. The anti-HIV potency was found to be correlated with the $\alpha$-glucosidase I inhibitory activity, leading to the hypothesis that the anti-HIV activity was related to the inhibition of $\alpha$-glucosidase I [15]. However, a series of natural epimers of $\alpha$-homonojirimycin and $N$-alkylated derivatives were isolated or synthesised, and it was observed that $\alpha$ homonojirimycin (6) and $N$-methyl- $\alpha$-homonojirimycin (7) were more potent inhibitors of $\alpha$-glucosidase I than 1-deoxynojirimycin or castanospermine. Nevertheless, only the two latter compounds showed a significant anti-HIV-1 activity [16], suggesting that the HIV-inhibitory activity may be due to other factors than inhibition of $\alpha$-glucosidase I.

Cepharantine (8) is a biscoclaurine alkaloid, isolated from Stephania cepharantha. It has been shown to possess anti-inflammatory, antiallergic, and immunomodulatory activities in vivo [17], [18]. Its effects on mammalian cells, and the implications for cancer, shock, and inflammatory diseases have recently been reviewed [19]. It is known that several inflammatory cytokines affect the progression and pathogenesis of HIV-1 infection [20]. Therefore, the inhibitory effects of cepharanthine on TNF- $\alpha$ and phorbol 12-myristate-13-acetate (PMA)-induced HIV-1 replication in chronically infected monocytic and $\mathrm{T}$ lymphocytic cell lines were evaluated. Cepharanthine was a highly potent inhibitor of HIV-1 in the monocytic cell line, but not in the T lymphocytic cell line [21]. It also suppressed HIV-1 long terminal repeat (LTR)driven gene expression through inhibition of NF- $\kappa$ B activation.

The related bisbenzylisoquinoline alkaloid cycleanine (9) was evaluated against HIV-1 and HIV-2. It showed activity against HIV-2 with an $\mathrm{IC}_{50}$ of $1.83 \mu \mathrm{g} / \mathrm{mL}$ but was at least 10 -fold less active against HIV-1. The selectivity index of cycleanine against HIV-2 was 9, with a $\mathrm{CC}_{50}$ of $15.68 \mu \mathrm{g} / \mathrm{mL}$ [22].

Two new sesquiterpene pyridine alkaloids, triptonines A (10) and $B$ (11), were isolated from the methanolic extract of the root bark of Tripterygium hypoglaucum [23]. Their IC $_{50}$ values against HIV replication were 2.54 and $<0.10 \mu \mathrm{g} / \mathrm{mL}$, respectively, with a selectivity index (SI) of $>39.4$ and $>1000$.

The $\beta$-carboline skeleton was found to be present in various antiHIV alkaloids. The well-known $\beta$-carboline alkaloid harman (12) isolated from Symplocos setchuensis, indigenous in southern China, was found to inhibit HIV replication $\left(\mathrm{IC}_{50}=10.7 \mu \mathrm{M}, \mathrm{SI}=10.4\right)$ [24]. Substitution of the indole nitrogen with 1-methyl, 7-methoxy, or an alkyl group increased its activity. The most active derivative was $N$-butylharmine (13) $\left(\mathrm{IC}_{50}=0.037 \mu \mathrm{M}, \mathrm{SI}=210\right.$ ). The new carbazole alkaloid siamenol (14) was isolated from an extract of Murraya siamensis. It inhibited HIV with an IC $_{50}$ value of $2.6 \mu \mathrm{g} / \mathrm{mL}$, reaching $50-60 \%$ maximum protection in the XTTtetrazolium assay, and it was more active than the related $\beta$-carboline alkaloid mahanimbilol isolated from the same source [25]. Anti-HIV carbazoles were also obtained from Clausena excavata, used in Thai folk medicine. O-Methylmukonal (15), 3formyl-2,7-dimethoxycarbazole (16) and clauszoline J (17) displayed anti-HIV-1 activity in a syncytal assay with $\mathrm{IC}_{50}$ values of $12,29.1$ and $34.2 \mu \mathrm{M}$, respectively, and with a selectivity index of 56.7, 8.0 and 1.6, respectively [26]. The $\beta$-carboline derivative 5methoxycanthinone (18), isolated from Leitneria floridana, a rare tree or shrub restricted to scattered wet sites in the southern Atlantic and Gulf coastal plains of the United States, was a potent 


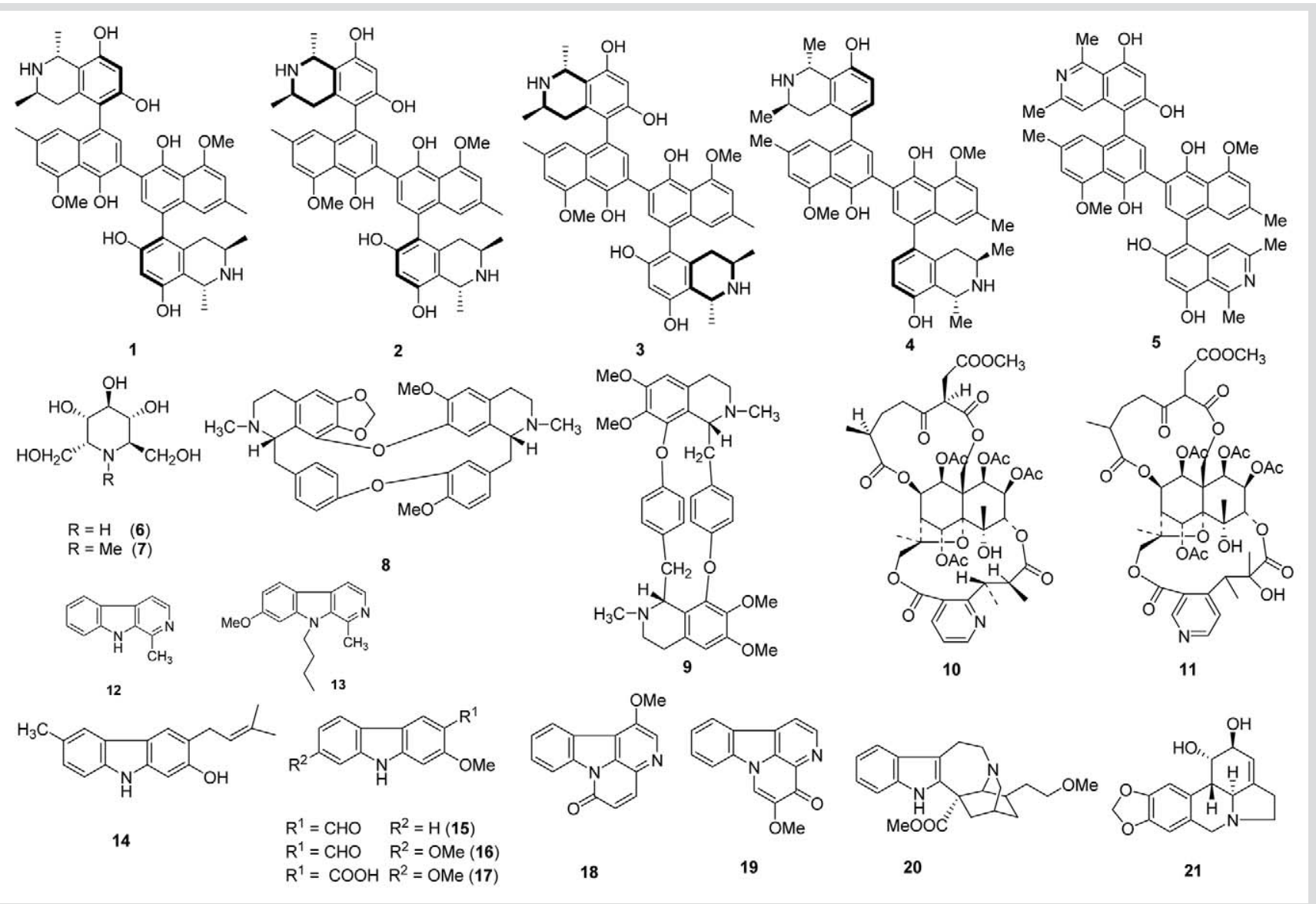

Fig. 1 Alkaloids.

anti-HIV agent ( IC $_{50} 0.26 \mu \mathrm{g} / \mathrm{mL}$; SI > 391) [27]. Also the canthin4-one drymaritin (19), obtained from Drymaria diandra from Taiwan, showed anti-HIV activity ( IC $_{50} 0.69 \mu \mathrm{g} / \mathrm{mL}$; SI 20.6), indicating the potential of canthinones as anti-HIV leads [28].

The Iboga alkaloid congener 18-methoxycoronaridine (20), for which in vitro leishmanicidal and in vivo anti-addiction properties had already been described, also inhibited HIV-1 replication in human peripheral blood mononuclear cells and in monocytederived macrophages [29]. According to the test system, $\mathrm{IC}_{50}$ values in the range of 9.5 to $23 \mu \mathrm{M}$ were obtained, with an SI of 14.5 to 34.5. In this concentration range, 18-methoxycoronaridine moderately reduced the polymerase activity of recombinant HIV-1 reverse transcriptase $\left(\mathrm{IC}_{50}=69.4 \mu \mathrm{M}\right)$. The antileishmanial activity may be useful for treating HIV-1 infected patients coinfected with Leishmania.

The antiviral properties of Amaryllidaceae alkaloids such as lycorine (21) had already been reported many years ago [30]. More recently, anti-HIV activity was observed for lycorine, homolycorine, trisphaeridine and haemanthamine. $\mathrm{IC}_{50}$ values in the range of $0.4-7.3 \mu \mathrm{g} / \mathrm{mL}$ were obtained, but the cytotoxicities were similar, leading to a low SI for all alkaloids (1.3 - 1.9) [31]. Remarkably, also a very simple compound such as indole-3-carboxylic acid showed anti-HIV activity, with an $\mathrm{IC}_{50}$ of $2.41 \mu \mathrm{g} / \mathrm{mL}$ and an SI of 6.79 [32].

\section{Carbohydrates}

The HIV regulatory gene tat is essential for viral replication. The tat protein is released from HIV-1 infected cells, enters new cells in an active form, and stimulates the transcriptional activity of HIV-LTR [33]. Inhibition of tat activity by pentosan polysulphate (22) [34] and heparin (23) [35] leads to anti-HIV-1 activity; selective 2-O-, 6-O-, or $\mathrm{N}$-desulphation of heparin prevented the interaction with tat ( $\bullet$ Fig. 2). Sulphated dextrin derivatives were also able to inhibit HIV-1 tat, whereas unsulphated dextrin did not [36].

Sulphated polysaccharides have already been known for a long time as potent inhibitors of HIV-1 and -2 replication in vitro [37], [38]. They are characterised by the following properties: (a) broad activity against enveloped viruses, including HIV and HSV; (2) low induction of viral resistance in cell cultures; (3) inhibition of virus adsorption to the cells; and (4) inhibition of syncytium (giant cell) formation between HIV-infected and normal $\mathrm{CD} 4^{+} \mathrm{T}$ cells. The latter point may be important for the depletion of $\mathrm{CD} 4^{+} \mathrm{T}$ cells in AIDS patients. The anti-HIV activity of sulphated polysaccharides is due to shielding off the positively charged amino acid residues in the V3 loop of the viral envelope glycoprotein gp120 [38]. In this way, viral attachment to cell surface heparan sulphate is prevented. This is a primary binding site, followed by a more specific binding to the CD4 receptor. Resistance of HIV-1 to dextran sulphate (24) seemed to be located in the env genome of HIV, and specifically in the V3 loop domain [39].

More than 15 years ago, the in vivo activity of dextran sulphate against HIV was found to be disappointing, both after oral or intravenous administration [40], [41]. This was due to its poor oral bioavailability, its short plasma half-life, partial inactivation by plasma components, and poor ability to penetrate infected cells 


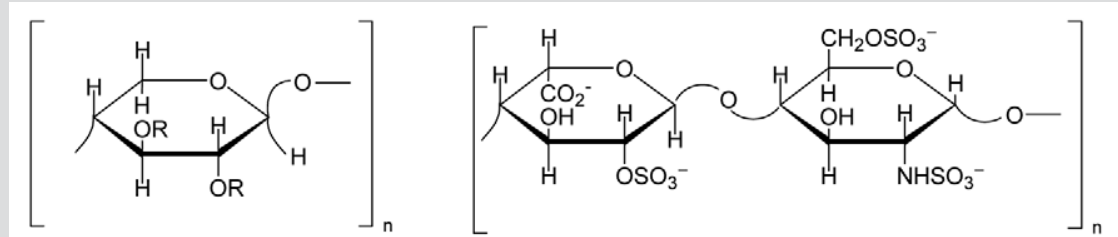

Fig. 2 Carbohydrates.

$22\left(\mathrm{R}=\mathrm{H}\right.$ or $\left.\mathrm{SO}_{3}^{-}\right)$

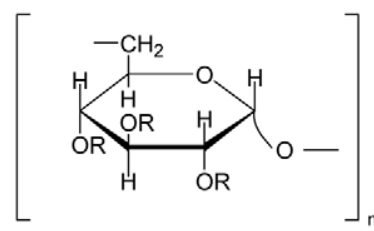

$24\left(\mathrm{R}=\mathrm{H}\right.$ or $\left.\mathrm{SO}_{3}{ }^{-}\right)$

[37]. However, it was reported that dextran sulphate was absorbed rapidly in humans after oral administration and could be found in plasma, lymphocytes, and urine [42]. In an open phase I/II doseescalation study in which six AIDS patients were treated with intraperitoneally administered dextrin 2-sulphate, a significant decrease in viral load was observed [43]. The question if sulphated polysaccharides can be useful anti-HIV drugs after oral or parenteral administration, or as a gel formulation (e.g., on condoms) in the prevention of sexually transmitted HIV remains a matter of debate [44]. The development of new drug delivery systems such as liposomes may improve the therapeutic efficacy of sulphated polysaccharides.

A sulphated polysaccharide with fucose as the main component was isolated from the water extract of a brown alga Sargassum horneri. It showed potent antiviral activity against Herpes simplex virus type 1, human cytomegalovirus and HIV-1 [45]. Time-of-addition experiments suggested that it inhibited not only the initial stages of viral infection, but also intracellular replication stages. The same observations were made for rhamnan sulphate, a natural sulphated polysaccharide isolated from the seaweed Monostroma latissimum, composed of large amounts of 1,2- and 1,3-linked $\alpha$-L-rhamnose residues with small amounts of their branching residues, which was active against the same range of viruses. Rhamnan sulphate and AZT acted synergistically in their anti-HIV effect [46]. The gametic, carposporic and tetrasporic reproductive stages of the Mediterranean red alga Asparagopsis armata yielded sulphated galactans with a galactose:3,6-anhydrogalactose:sulphates molar ratio of $1: 0.01: 1.23,1: 0.04: 0.47$, and $1: 0.01: 1.13$, respectively. The carposporic polysaccharide with the lowest sulphate ratio was ineffective against HIV- 1 replication up to $100 \mu \mathrm{g} / \mathrm{mL}$, in contrast to the other galactans which inhibited HIV-1 replication at 10 and $8 \mu \mathrm{g} / \mathrm{mL}$, as measured by HIV-induced syncytium formation and reverse transcriptase activity in cell-free culture supernatant [47]. Calcium spirulan, a sulphated polysaccharide from Arthrospira platensis (formerly Spirulina platensis), consists mainly of two types of disaccharide repeating units, 0 -hexuronosylrhamnose and O-rhamnosyl-3-O-methylrhamnose. A broad spectrum of antiviral activity of calcium spirulan and spirulan-like substances was reported, including herpes viruses, paramyxo viruses, influenza viruses, and HIV-1. With regard to herpes viruses, antiviral effects were most pronounced after preincubation prior to virus addition, indicating virus entry as the primary target. However, in the case of human cytomegalovirus,

it was clearly demonstrated that intracellular steps also contributed to the antiviral effect. In the case of HIV-1, inhibition occurred at a stage later than viral entry [48].

\section{Coumarins}

A screening program by the U.S. National Cancer Institute (NCI) has led to the isolation of 4-propyldipyranocoumarins or calanolides from Calophyllum lanigerum, a tropical rainforest tree [49]. (+)-Calanolide A (25) was the most active against HIV-1 and was classified as an NNRTI, but its HIV sensitivity/resistance profile is different from other NNRTIs ( Fig. 3). Other Calophyllum cou-<smiles>CCCc1cc(=O)oc2c3c(c4c(c12)OC(C)(C)C=C4)OC(C)[C@H](C)[C@H]3O</smiles>

25<smiles>CCCc1cc(=O)oc2c3c(c4c(c12)O[C@H](C)[C@H](C)[C@H]4O)OC(C)(C)C=C3</smiles>

28<smiles>[R1]OC1c2c(ccc3ccc(=O)oc23)OC(C)(C)C1O[R1]</smiles>

$\mathrm{R}^{1}=3^{\prime}$-methylbutanoyl, $\mathrm{R}^{2}=$ acetyl

$\mathrm{R}^{1}=(-)$-camphanoyl, $\mathrm{R}^{2}=(-)-$ camphanoyl $(31)$

Fig. 3 Coumarins. 
marins could be classified into three groups, based on the C-4 substituent of the lactone ring: calanolides with an $n$-propyl group, inophyllums having a phenyl group and cordatolides with a methyl group in this position [50]. The methyl groups at C-10 and C-11, and a free hydroxy group at C-12 are important for the anti-HIV-1 activity [51], [52]. In calanolides, the configuration of C-12 should be $S$, but can be $R$ or $S$ in inophyllums [53]. Cordatolides A (26) and B (27) were about 50 times less active against HIV-1 reverse transcriptase than (+)-calanolide A, indicating that the nature of C-4 substitution is important [54].

(+)-Calanolide A has been extensively studied because of its unique sensitivity/resistance profile [55]; [56], its synergistic effect in combination with other anti-HIV drugs [57] and its pharmacokinetic profile [58], [59], [60], [61], [62]. The interaction of NNRTIs at the hydrophobic non-nucleoside binding site of HIV-1 reverse transcriptase is highly specific. A single amino acid change in the NNRTI active site drastically changes the antiHIV-1 activity of these NNRTIs. (+)-Calanolide A and nevirapine exhibited different activities against Y181C- and Y188H-mutated reverse transcriptase. Both compounds bind to reverse transcriptase in the NNRTI common binding site, but in a mechanistically different fashion. (+)-Calanolide A enhanced anti-HIV-1 activity against viruses with Y181C mutation, but the Y188 H substitution in reverse transcriptase resulted in about 30 -fold resistance. In contrast, Y181C substitution in reverse transcriptase resulted in about 90 -fold resistance to nevirapine, while Y188 H substitution did not decrease the sensitivity to nevirapine at all [55].

(-)-Calanolide B (costatolide) (28) and (-)-dihydrocalanolide B (dihydrocostatolide) (29) were similar to (+)-calanolide A with regard to their sensitivity/resistance profile for viruses with Y188 H or Y181C amino acid changes in their reverse transcriptase [56]. Calanolides act synergistically in combination with lamivudine and nelfinavir in vitro [57]. They represent a distinct subgroup of the NNRTI family and may be useful in combination therapy with other anti-HIV drugs.

The in vivo anti-HIV-1 efficacy of (+)-calanolide A was demonstrated in a hollow fibre mouse model after oral or parenteral administration once or twice daily in the subcutaneous site or the peritoneal cavity [58]. (+)-Calanolide A has been quantified using a validated HPLC method in rat, dog and human plasma. It was demonstrated that epimerisation of the 12-OH group of (+)-calanolide A to its inactive epimer (+)-calanolide B did not occur after oral administration in humans [59]. The pharmacokinetic profile of $(+)$-calanolide $\mathrm{A}$ and $(+)$-dihydrocalanolide $\mathrm{A}$ was comparable, but the oral bioavailability of $(+)$-dihydrocalanolide A was markedly better than that of $(+)$-calanolide $\mathrm{A}$ [60].

The safety and pharmacokinetics of (+)-calanolide A was evaluated in both healthy and HIV-infected volunteers [61]. In HIVnegative volunteers, the toxicity of (+)-calanolide A after oral administration was minimal with dizziness, taste perversion, headache and nausea as the most reported adverse effects [62]. In HIV-infected volunteers, the $\mathrm{C}_{\max }$ and AUC increased doseproportionally, indicating linear pharmacokinetics. No drug accumulation was observed, although (+)-calanolide A has a relatively long elimination half-life $(15-20 \mathrm{~h})$. The viral load reduction was dose-dependent (mean reduction from baseline of -0.81 $\log _{10}$ ). However, the pharmacokinetic parameters showed high intrasubject variability and the results of a phase IB study were rather disappointing. A significant drug-related toxicity (fever, rash) was observed at the highest dose of $600 \mathrm{mg}$. A decrease in
CD4 cell count was observed in Asian patients, but not in Caucasian and black US patients.

In addition to the calanolides, khellolactone coumarins have also served as lead compounds for new anti-HIV agents. The original lead, suksdorfin (30), was obtained from Lomatium sukdorfsii. Its $\mathrm{IC}_{50}$ against HIV-1 was $2.6 \mu \mathrm{M}$. The $3^{\prime} \mathrm{R}, 4^{\prime} \mathrm{R}$-di-O-(-)-camphanoyl-(+)-cis-khellolactone (31) had potent anti-HIV activity $\left(\mathrm{IC}_{50}\right.$ $0.4 \mathrm{nM}$, SI 136,719), and was selected for preclinical studies [53], [63]. Also thia analogues were found to merit attention as anti-HIV agents [64].

Also other types of coumarins showed more or less pronounced anti-HIV activity [26], [32,63]. Mesuol (32), a naturally occurring 4-phenylcoumarin, was found to inhibit HIV-1 replication by targeting the NF- $\mathrm{B}$ pathway. It inhibited the phosphorylation and the transcriptional activity of the NF- $\kappa$ B p65 subunit in TNF $\alpha$-stimulated cells [65].

\section{Flavonoids}

Flavonoids are capable of inhibiting a wide variety of enzymes, including several critical enzymes involved in the HIV life cycle, such as reverse transcriptase [66], viral protease [67], and integrase [68]. Another important enzyme for HIV replication is casein kinase II, a cAMP-, cGMP-, and $\mathrm{Ca}^{2+} /$ phospholipid-independent serine/threonine protein kinase that phosphorylates several HIV-1 structural proteins in HIV-1 infected cells. Flavonoids such as quercetin, chrysin, and (-)-epigallocatechin 3-Ogallate (33) were able to inhibit casein kinase II [69], [70], [71] ( Fig. 4). However, the biological significance of casein kinase II in HIV-1 replication and its inhibition by flavonoids are not completely understood yet.

The chalcone 2-methoxy-3-methyl-4,6-dihydroxy-5-(3'-hydroxy)-cinnamoylbenzaldehyde (34) isolated from the roots of Desmos spp. showed potent anti-HIV activity $\left(\mathrm{IC}_{50}=0.022 \mu \mathrm{g} /\right.$ $\mathrm{mL}, \mathrm{SI}=489$ ) [72]. The compound can now be synthesised in five or six simple steps without any protecting groups [73]. Six chalcones were isolated from the methanolic extract of Boesenbergia pandurata rhizomes and tested for anti-HIV-1 protease activity. Hydroxypanduratin A (35) showed the highest activity with an $\mathrm{IC}_{50}$ value of $5.6 \mu \mathrm{M}$. An SAR of these chalcones was summarised as follows: a) a hydroxy moiety at position 4 conferred higher activity than a methoxy group; b) prenylation of dihydrochalcone was essential for activity; c) hydroxylation at position 4" reduced activity; and d) introduction of a double bond at $\mathrm{C}^{\prime}$ 'and $\mathrm{C6}^{\prime}$ of chalcones gave higher activity [74].

Flavanones bearing an $\mathrm{OH}$ group in position $\mathrm{C}-3^{\prime}$, such as taxifolin (36), inhibited viral protease, reverse transcriptase, CD4/ gp120 interaction by binding to the V3 loop of gp120, and showed binding to non-specific proteins. However, flavanones without this $\mathrm{OH}$ group, such as aromadendrin (37), were more specific in their antiviral activity and inhibited the CD4/gp120 interaction, but not viral protease or reverse transcriptase [75]. Another example of non-specific activity is (-)-epigallocatechin 3-O-gallate (33), which exhibited a destructive effect on viral particles and post-adsorption entry and inhibited viral protease and reverse transcriptase [76]. Recently, it was stated that (-)epigallocatechin 3-O-gallate at concentrations equivalent to those obtained by the consumption of green tea was able to reduce the attachment of gp 120 to CD4 by a factor of 10-fold [77]. Thalassiolins A - C are natural flavones isolated from the Caribbean sea grass Thalassia testudinum with HIV integrase inhibition [78]. Thalassiolin A (38) was the most active and inhibited terminal cleavage and $\mathrm{Mg}^{2+}$-dependent strand transfer reaction 
<smiles>O=C(O[C@H]1Cc2c(O)cc(O)cc2O[C@H]1c1cc(O)c(O)c(O)c1)c1cc(O)c(O)c(O)c1</smiles><smiles>COc1c(C)c(O)c(C(=O)/C=C(\O)c2ccccc2)c(O)c1C=O</smiles>

33<smiles>CC(C)=CC[C@H]1C(C)=CCC[C@H]1C(=O)c1c(O)cc(O)cc1O</smiles>
35<smiles>O=c1cc(-c2ccc(O)c(O)c2)oc2cc(OC3OC(CO)[C@@H](O)[C@H](O)[C@H]3OS(=O)(=O)O)cc(O)c12</smiles>

38<smiles>COc1cc(O)c2c(=O)cc(-c3ccc(Oc4cc(-c5cc(=O)c6c(O)cc(O)cc6o5)ccc4O)cc3)oc2c1</smiles><smiles>COc1cc(O)c2c(c1)OC(c1ccc(Oc3cc(-c4cc(=O)c5c(O)cc(O)cc5o4)ccc3O)cc1)CC2=O</smiles>

Fig. 4 Flavonoids.

at low micromolar concentrations. Long-term passage of cells with thalassiolin A did not lead to resistant viruses.

Some prenylated flavanones and flavones known for their phytoestrogenic activity, also showed moderate anti-HIV activity, but accompanied by a high cytotoxicity and very low selectivity [79], [80]. Xanthohumol (39), purified from hops (Humulus lupulus), is a constituent of beer, a major dietary source of prenylated flavonoids and a natural product with multiple biofunctions. It was shown to inhibit HIV-1 induced cytopathic effects (CPE), and production of viral p24 antigen and reverse transcriptase in C8166 lymphocytes at non-cytotoxic concentrations [81]. The IC $\mathrm{I}_{50}$ values were, respectively, $0.82,1.28$ and $0.50 \mu \mathrm{g} / \mathrm{mL}$ and an SI of about 10.8. The target of xanthohumol on HIV-1 may be on the steps post reverse transcription.

Biflavonoids consisting of two apigenin units, such as robustaflavone and hinokiflavone inhibited HIV-1 reverse transcriptase with $\mathrm{IC}_{50}$ values of 65 and $62 \mu \mathrm{M}$, while apigenin itself was about seven times less active [82]. Five new flavonoid glycosides with moderate to weak anti-HIV activity were isolated from Ochna integerrima [83] together with two known biflavonoids, ochnaflavone 7"-O-methyl ether (40) and 2",3"-dihydroochnaflavone 7"-O-methyl ether (41) showing significant anti-HIV-1 activities in the syncytium assay with $\mathrm{IC}_{50}$ values of 2.0 and $0.9 \mu \mathrm{g} / \mathrm{mL}$, respectively. Their $\mathrm{IC}_{50}$ values for inhibition of HIV-1 reverse transcriptase are comparable to the syncytium assay values, suggesting reverse transcriptase as a potential mechanism of action.

The correlation between anti-HIV activity of flavonoids and their structural properties were studied [84], [85], [86]. Electronegativity, LUMO (the energy of the lowest unoccupied molecular orbital), and the charges on atoms C-3 and C-7, were the molecular parameters allowing one to classify the flavonoids into active and less active anti-HIV agents [84], [86].

Sodium rutin sulphate showed a broad anti-HIV activity against R5 and X4 viruses with an SI ranging from 197 to 575 [87]. Like the sulphated polysaccharides, it has a poor oral bioavailability [88] and a short plasma half-life [89], indicating that it may be a good candidate for topical microbicide development.

\section{Lignans}

The antiviral activity of lignans was reviewed in 1998 by Charlton [90] and was found to be rather moderate for most products [91], [92], [93], [94]. Mechanisms of action included tubulin binding, inhibition of reverse transcriptase, integrase, and topoisomerase. Whereas podophyllotoxin and its derivatives were the most prominent representatives of the tubulin-binding lignans, various classes of lignans, such as dibenzylbutyrolactones, dibenzylbutanes, dibenzylcyclooctadienes, and aryltetralins inhibited reverse transcriptase.

Podophyllotoxin (42) is a lignan isolated from the roots of the North American Podophyllum peltatum Linnaeus, the Tibetan $P$. emodi Wall, or the Taiwanese species Podophyllum pleinthum ( $\bullet$ Fig.5). Extensive structural modification and anti-tumour studies of podophyllotoxin have resulted in clinically useful anti-cancer drugs, such as etoposide and teniposide. In addition, it is also used as an antiviral agent in treatment of anogenital warts [3]. Recently, several podophyllotoxin derivatives were synthesised that showed potent inhibitory effects on HIV-1 [95], [96].

Bioassay-guided fractionation of an ethanolic extract of the fruits of Schisandra rubriflora led to the isolation of new dibenzocyclooctadiene lignans, called rubrisandrins $A$ and $B$, together with 11 known lignans [97]. ( \pm )-Gomisin $\mathrm{M}_{1}$ (43) was the most active anti-HIV-1 compound with an $\mathrm{IC}_{50}$ value of less than $0.65 \mu \mathrm{M}$ and an SI greater than 68 . The other lignans possessed a low anti-HIV-1 activity and a low SI. During an HTS campaign to find novel HIV integrase inhibitors from natural products, the $\mathrm{MeOH}$ extract from the buds of Eucalyptus globoidea was found to be active [98]. Bioassay-guided fractionation led to the purification of a new lignan, globoidnan A (44) that inhibited the combined 3' processing and strand transfer activity of HIV integrase with an $\mathrm{IC}_{50}$ value of $0.64 \mu \mathrm{M}$. In contrast to $\mathrm{L}$-chicoric acid, the diketo acid motif containing globoidnan A showed no activity in the whole cell anti-HIV assay. Interestingly, despite the presence of the three bis-catechol moieties, no cytotoxicity was observed at the highest test concentration of $50 \mu \mathrm{M}$.

Some dibenzylbutyrolactone-type lignans were isolated from Phenax angustifolius and the phenaxolactone 2-hydroxy-2(3',4'-dihydroxyphenyl)-methyl-3-(3",4"'-dimethoxyphenyl)methyl- $\gamma$-butyrolactone (45) had an $\mathrm{IC}_{50}$ value of $3 \mu \mathrm{M}$ and an SI of 37.3, requiring further SAR studies [99]. Moderate antiHIV activity was observed for their glycosyl derivatives at the 
<smiles>COc1cc([C@H]2c3cc4c(cc3[C@@H](O)[C@@H]3COC(=O)[C@@H]23)OCO4)cc(OC)c1OC</smiles>

42<smiles>O=C(OC(Cc1ccc(O)c(O)c1)C(=O)O)c1cc(-c2ccc(O)c(O)c2)c2cc(O)c(O)cc2c1</smiles>

44<smiles>COc1cc(CC2C[C@H](C)[C@@H](C)C2)c(-c2c(O)c(OC)c(OC)c3c2OCO3)cc1OC</smiles>

43<smiles>COc1ccc(C[C@H]2COC(=O)[C@]2(O)Cc2ccc(O)c(O)c2)cc1OC</smiles>

45

Fig. 5 Lignans.

C-4' position. Preliminary mechanism of action studies suggested inhibition of an early step in the virus replicative cycle.

\section{Phenolics}

There has been discussion about the real anti-HIV-1 mechanism of dicaffeoylquinic acids (DCQAs) and dicaffeoyltartaric acids (DCTAs). It was suggested that HIV-1 integrase, an enzyme catalysing the insertion of viral DNA into the genome of the host cell, was their target [100], [101], [102]. In enzymatic assays, DCQAs such as 3,5-dicaffeoylquinic acid (46), and DCTAs such as Lchicoric acid (47), showed a ten- to hundred-fold higher preference for inhibition of HIV integrase than of HIV reverse tran-

scriptase ( Fig. 6) [100]. In the series of the bis-catechols, Lchicoric acid was the most active inhibitor of HIV integrase, while phenolic acids such as caffeic acid and chlorogenic acid were not active. The inhibition of HIV integrase by DCQAs was irreversible and not dependent on divalent cations [101]. An HIV-1 mutant containing a single glycine-to-serine substitution at position 140 of integrase was resistant to $\mathrm{L}$-chicoric acid, indicating that this compound is likely to interact at residues near the catalytic triad in the integrase active site [102]. However, this mechanism of action has been questioned [103]. HIV strains resistant to $\mathrm{L}$-chicoric acid contained several mutations in the V2, V3, and V4 loop regions of the envelope glycoprotein gp120, but not in the integrase enzyme. Furthermore, L-chicoric acid did not inhibit the replication of viral strains resistant to polyanionic compounds, such as dextran sulphate [103]. Therefore, the primary anti-HIV target of $\mathrm{L}$-chicoric acid and its analogues would be the envelope glycoprotein gp120. However, the most potent classes of integrase inhibitors with antiHIV activity are still the dicaffeoylquinic acids (DCQAs), dicaffeoyltartaric acids (DCTAs), and diketo acids (DKAs). Moreover, molecular modelling studies have identified a putative HIV integrase inhibitor-binding pocket for $\mathrm{L}$-chicoric acid and other integrase inhibitors [104], [105].

According to Lipinski's rule of 5 and Veber's bioavailability criteria, $\mathrm{L}$-chicoric acid is a rather poor drug candidate for the following reasons: a) limited cell permeability due to the diacid moiety, b) hydrolytic enzymatic instability of the two ester linkages, and c) potential toxicity of the two catechol moieties [106], [107]. On the other hand, the very potent $\mathrm{L}$-chicoric acid is an excellent lead compound for optimisation and indeed, a great number of DCQA and DCTA analogues were synthesised and evaluated as HIV-1 integrase inhibitors [108], [109], [110], [111], [112], [113]. Structure-activity relationship studies on these synthetic compounds demonstrated that $\mathrm{L}-$ and D-chicoric acid (48) exhibited similar anti-HIV-1 integrase activity. Removal of one or both carboxylic groups did not result in a significantly lower integrase inhibitory activity [110]. The bis-catechol moieties

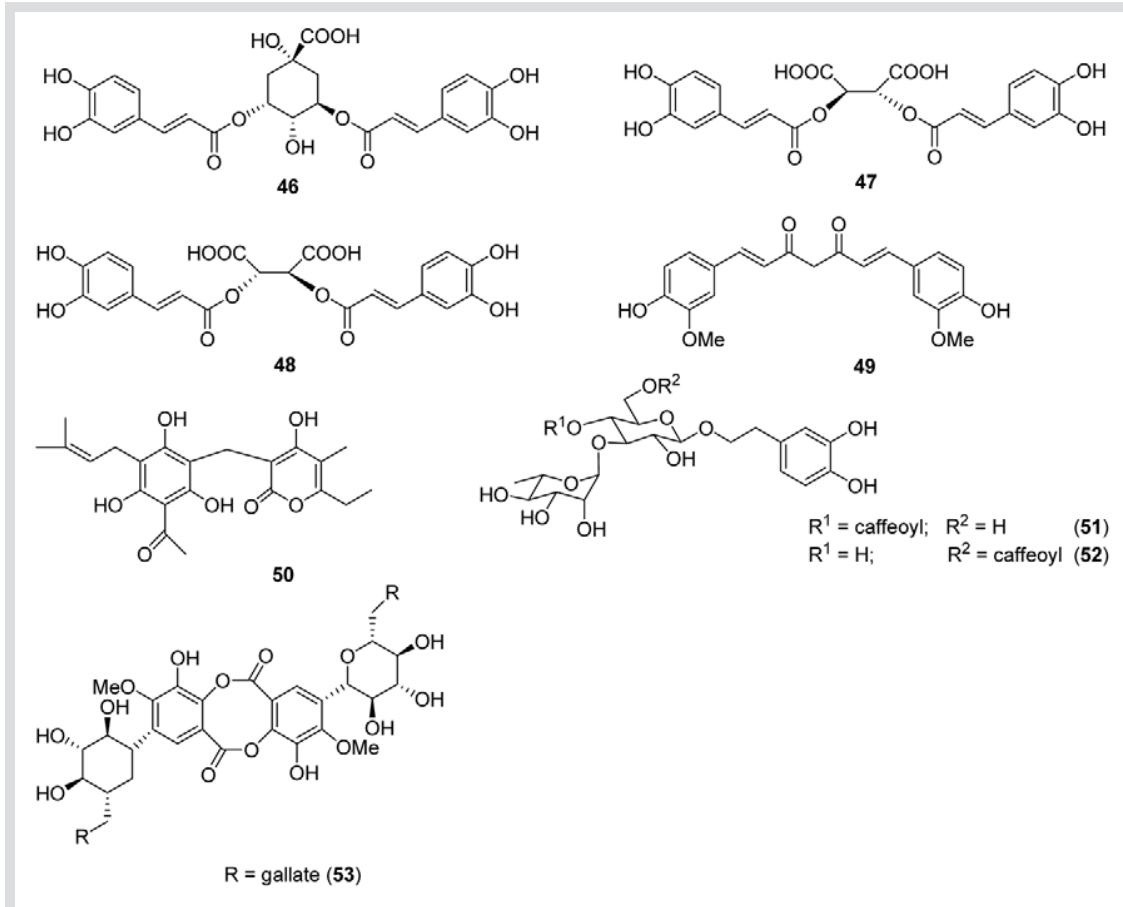

Fig. 6 Phenolics. 
were essential to obtain a high inhibitory activity of integrase [111], but acetylation had only a minor negative effect on the inhibition of HIV integrase [110].

Curcuma longa Linn. (Zingiberaceae) is a medicinal plant widely cultivated in tropical regions of Asia. Curcumin (49) is a yellow pigment isolated from the rhizomes of this plant and possesses a wide variety of biological activies, including anti-inflammatory and antioxidant activities. It is also able to inhibit different enzymatic activities, such as HIV-1 integrase, nuclear factor-kappaB activation and p300-specific HAT/factor acetyltransferase activity [114], [115], [116]. In the latter case, curcumin could inhibit the acetylation of HIV-Tat protein in vitro by p300 as well as proliferation of the virus, as revealed by the repression in syncytia formation upon curcumin treatment in Sup T1 cells [116].

An acetone extract of Helichrysum italicum spp. microphyllum yielded phloroglucinol $\alpha$-pyrone arzanol (50), a potent NF-kappaB inhibitor [117]. It also inhibited HIV-1 replication in T cells and the release of pro-inflammatory cytokines in LPS-stimulated primary monocytes. This compound is worthwhile investigating for developing a complementary anti-HIV strategy, targeting both viral and cellular factors [4]. From Clerodendron trichotomum, several phenylpropanoid glycosides were isolated and evaluated for their anti-HIV-1 integrase activity [118]. Acteoside (51) and an acteoside isomer (52) showed the highest activity with IC $_{50}$ values of 7.8 and $13.7 \mu \mathrm{M}$, respectively. A new dimeric lactone, ardimerin digallate (53) was isolated from the whole plants of Ardisia japonica and inhibited HIV-1 and HIV-2 RNase in vitro with $\mathrm{IC}_{50}$ values in the low micromolar concentrations [119].

\section{Proteins}

Proteins from higher plants active against HIV include ribosomeinactivating proteins (RIPs) and lectins [120]. RIPs are RNA Nglycosidases; they inactivate ribosomes through a site-specific deadenylation of the large ribosomal RNA [121]. A high number of RIPs have been identified in plants belonging to various families, particularly Caryophyllaceae, Sambucaceae, Cucurbitaceae, Euphorbiaceae, Phytolaccaceae and Poaceae [122]. For some RIPs, sensitisation and IgE induction have been demonstrated, so their allergenic and cross-reactive potential should be considered when applying them in therapy [123].

MAP30 is a plant protein with a molecular weight of $30 \mathrm{kDa}$ isolated from Momordica charantia with anti-tumour and anti-HIV properties [124], [125]. MAP30 was active against tumour-transformed or HIV-infected cells, while it showed no adverse effects on normal cells. In addition to its RNA N-glycosidase activity, MAP30 acted as a DNA glycosylase/apurinic lyase [126]. This may explain its apparent inhibition of HIV-1 integrase by rendering the HIV LTR an unsuitable substrate for HIV integrase as well as DNA gyrase. The DNA glycosylase/apurinic lyase activity of MAP30 [126] and other RIPs [127] suggested that the anti-HIV activity of RIPs was independent of their ribosome inactivation activity. Indeed, endopeptidase digestion of MAP30 and GAP31 resulted in the generation of peptide fragments with full antiviral and antitumour activity [128]. These fragments remained fully active in HIV integrase inhibition and HIV-LTR topological inactivation, but not ribosome inactivation. Therefore, it could be concluded that the antiviral and antitumour activities of MAP30 and GAP31 are independent of their ribosome inactivation activity.

Trichosanthin from the root tuber of Trichosanthes kirilowii was the first RIP found to inhibit HIV in vitro [129]. Clinical trials with trichosanthin showed that it induced anaphylactic reactions in AIDS patients after i. $v$. administration [130]. In order to reduce its antigenicity, the seven C-terminal amino acid residues were deleted, which resulted in a 2.7-fold decrease in antigenicity, but a 10-fold reduction in in vitro ribosome inactivation [131]. A recent study demonstrated that trichosanthin was more effective in inducing apoptosis in HIV-1 infected cells, which can explain partially the antiviral action [132].

Several plant RIPs, such as agrostin, gelonin, luffin, $\alpha$-momorcharin, $\beta$-momorcharin, saporin, and trichosanthin were evaluated as inhibitors of HIV-1 replication [133]. They exhibited a very weak suppressive effect on HIV-1 reverse transcriptase and HIV-1 protease, but apart from agrostin, all RIPs strongly inhibited HIV-1 integrase. However, it remains to be elucidated whether interference with integrase is the key mechanism for the anti-HIV activity of RIPs.

The glycoproteins gp120 and gp41 are present on the envelope of HIV and mediate the entry of the virus into host cells. Both gp120 and gp41 are heavily glycosylated, surrounding the receptor-binding regions. It is estimated that gp120 consists of $\mathrm{N}$ linked glycans for almost $50 \%$ of its molecular weight [134]. The glycans of HIV-1 gp120 consist to 33\% of the high-mannose type, $4 \%$ of the hybrid type and $63 \%$ of the complex type, the latter being predominantly glucosylated and/or sialylated. Carbohydrate-binding agents (CBAs) specifically targeting HIV-1 glycan shields efficiently inhibit HIV infection and prevent virus entry into target cells. In contrast to other existing anti-HIV agents, resistance development of HIV against CBAs may allow efficient immunological suppression of virus replication and virus clearance from the systemic circulation because of the exposure of previously hidden immunogenic epitopes on gp120. They may therefore represent the first available drugs for which chemotherapy may act in concert with an immunological response [135], [136]. Synergistic activity between CBAs and 1-deoxymannojirimycin was recently described [137]. The ( $\alpha 1,2)$-mannosidase I inhibitor 1-deoxymannojirimycin was found to potentiate the inhibitory activity of CBAs against wild-type HIV-1. In cell cultures infected with mutant HIV-1, strains containing $N$ glycan deletions in the gp120 envelope rendered the mutant virus susceptible to the inhibitory activity of 1-deoxymannojirimycin. Moreover, it was able to partially reverse the phenotypic resistance of CBAs to the mutant virus strains.

CBAs are almost exclusively of protein nature and can be divided into at least seven distinct groups of molecules depending on their origin: prokaryotes, sea corals, algae, fungi, higher plants, invertebrates, and vertebrates [138], [139]. In this review, the ( $\alpha 1-3)$ - and ( $\alpha 1-6)$-mannose- and $N$-acetylglucosamine (GlcNAc)-specific plant lectins and the cyanobacterial cyanovirin-N will be discussed in detail.

Plant lectins are the largest group of plant proteins with biological activities, including antimicrobial activity, immunostimulation/repression and anti-HIV activity [120]. Lectins are proteins bearing a non-catalytic domain that binds irreversibly to specific carbohydrates, normally through a monosaccharide-specific mechanism. Most plant lectins with HIV activity are derived from the monocot families Allilaceae, Amaryllidaceae and Orchidaceae or the dicot families Cecropiaceae, Fabaceae, Moraceae and Urticaceae. The vast majority of anti-HIV active plant lectins are directed against mannose oligomers. Two extensively studied mannose-specific plant lectins are Galanthus nivalis agglutinin (GNA) and Hippeastrum hybrid agglutinin (HHA). Recently, a higher inhibitory activity of HHA compared to GNA 
was demonstrated for HIV adsorption to the epithelial cell line HEC-1A, HIV transcytosis through HEC-1A cell line monolayer, HIV adsorption to monocyte-derived dendritic cells (MDDC), and HIV transfer from MDDC to T cells [140].

Systemic use of plant lectins to inhibit HIV infection may be questionable due to their antigenic (immunogenic) properties and short plasma half-life. However, local (intravaginal) application as a gel or cream formulation may avoid these disadvantages and may open novel perspectives to develop plant lectins as microbicides. Therefore, Balzarini et al. investigated GNA and HHA for their potential as microbicides [141], [142]. Both proteins inhibited a wide variety of HIV-1 and -2 strains and clinical isolates in different cell types. Short exposure of the lectins to cell-free virus particles or persistently HIV-infected HUT-78 cells markedly decreased HIV infectivity and increased the microbicidal activity of the plant lectins. Selection of HIV-1 strains with different levels of resistance to the two mannose-specific lectins showed that there was no cross-resistance to any other HIV entry inhibitor, including T-20 and cyanovirin [142]. They also exhibited desirable properties for formulation studies, such as stability at high temperatures and low $\mathrm{pH}$ for prolonged time periods, odourless and tasteless, and they can be easily formulated in gel preparations [141].

The only GlcNAc-specific plant lectin (Urtica dioica agglutinin or UDA) with a pronounced anti-HIV activity was isolated from Urtica dioica. It is an 8.5-kDa monomeric protein having two carbohydrate-binding sites with different affinities and ranks among the smallest plant lectins. It inhibited HIV-1- and -2-induced cytopathogenicity and syncytium formation of HIV-infected HUT-78 cells and CD4 ${ }^{+}$MOLT- 4 cells [143]. In contrast to the mannose-binding proteins, which had a 50 - to 100 -fold decreased antiviral activity against the UDA-exposed mutant viruses, UDA only showed a slightly lower antiviral activity, even against those mutant virus strains lacking about $40 \%$ of the glycosylation sites in their gp120 envelope [135]. UDA was free of toxicity when given intravenously to mice at doses up to $25 \mathrm{mg} /$ $\mathrm{kg}$ body weight. It has also been reported that UDA at high concentrations did not agglutinate human red blood cells in cell culture and was poorly mitogenic.

Another interesting lectin was isolated from the rhizomes of Polygonatum cyrtonema Hua and was 10 - to 100 -fold more potent than other tested CBAs including GNA, while it was about 10-fold less toxic than GNA in MT-4 and CEM cells [144]. In contrast to other lectins from the Liliaceae family, it exhibited a higher affinity for both mannose and sialic acid.

Lectins from Phaseolus vulgaris, Momordica charantia, and Ricinus communis were able to inhibit HIV-1 reverse transcriptase [145], while lectins from Myrianthus holstii [146] showed an inhibitory activity against the HIV envelope protein gp120. Two plant proteins, MRK29 [147] and ginkbilobin [148], have been isolated from the fruits of Momordica charantia and the seeds of Ginkgo biloba, respectively. Both compounds inhibited HIV-1 reverse transcriptase, but MRK29 was about hundred times more active.

Cyanovirin-N, originally isolated from an aqueous extract of the cyanobacterium Nostoc ellipsosporum, is the first prokaryotic mannose-specific lectin with a potent anti-HIV activity [149], [150]. This protein consists of a single chain containing 101 residues and its amino acid sequence shows obvious duplication. The protein is highly resistant to degradation and shows no loss of structural integrity or antiviral activity after treatment with detergents, denaturants, organic solvents, freezing and heating up to $100{ }^{\circ} \mathrm{C}$ [149]. Until now, cyanovirin-N is the only CBA for which efficacy and safety was demonstrated in a chimeric simian immunodeficiency virus (SIV)/HIV-1 virus infection in monkey studies when applied intravaginally or rectally as a topical microbicide [151], [152]. By exposing HIV-1 infected CEM cell cultures to increasing concentrations of cyanovirin-N, a total of eight different amino acid mutations exclusively located at $\mathrm{N}$ glycosylation sites in the envelope surface gp120 were observed. The extent of the decrease of antiviral activity against the mutated virus strains was markedly less pronounced than observed for the ( $\alpha 1,3)$ - and ( $\alpha 1,6)$-mannose-specific plant lectins, Hippeastrum hybrid agglutinin and Galanthus nivalis agglutinin, pointing to the existence of a higher genetic barrier for cyanovirin-N [138]. Whereas the antiviral and in vitro antiproliferative activity of cyanovirin-N can be efficiently reversed by mannane, its pronounced mitogenic activity on peripheral blood mononuclear cells remained unaffected. Therefore, careful monitoring of potential side effects should be required if applied as a microbicidal drug. Nowadays, studies are ongoing to express and release cyanovirin-N in commensal lactobacilli or Streptococcus gordonii to create a microbicidal environment in the vaginal ecology [153], [154], [155]. Other algal lectins with a significant antiHIV activity are scytovirin, Microcystis viridis lectin, and griffith$\sin$ [156], [157], [158].

\section{Quinones/Xanthones}

From several plants, new and known xanthones were isolated and evaluated for their anti-HIV acitivity [79], [159], [160], [161]. In general, most xanthones showed a weak or moderate activity against HIV, mostly due to their toxicity.

\section{Tannins}

The vegetable tannins can be divided into two classes: hydrolysable and non-hydrolysable or condensed tannins [162]. The first group consists of polyesters of gallic and hexahydroxydiphenic acids (gallotannins and ellagitannins, respectively). The condensed tannins are oligomers and polymers composed of flavan-3-ol moieties, commonly referred to as proanthocyanidins [163].

A proanthocyanidin polymer fraction (MW 1500 - 2000 Da) from Cupressus sempervirens showed antiviral activity against the retroviruses HIV and HTLV IIIB ( IC $_{50}$ values from 1.5 to $15 \mu \mathrm{g} / \mathrm{mL}$ and 5 to $25 \mu \mathrm{g} / \mathrm{mL}$, respectively) [164]. Epigallocatechin$(4 \beta \rightarrow 8,2 \beta \rightarrow 0-7)$-epicatechin (54) inhibited HIV-1 protease at $70 \mu \mathrm{g} / \mathrm{mL}$, but proanthocyanidin $\mathrm{A}_{2}$ (55) was not active up to a concentration of $100 \mu \mathrm{g} / \mathrm{mL}$ ( $\bullet$ Fig. 7) [165]. However, a structure-anti-HIV-1 activity relationship study of a series of proanthocyanidin oligomers showed that proanthocyanidin $A_{2}$ was the most interesting compound with an SI of 24 [166]. Proanthocyanidin $A_{1}$ (56), which only differs from proanthocyanidin $A_{2}$ in its terminal (+)-catechin unit, only had an SI of 10 , which is still larger than procyanidins with a single linkage (the B-series).

Catechins and theaflavins are two groups of natural polyphenols found in green and black tea, respectively. In a comparative study, the theaflavin derivatives showed the highest anti-HIV-1 activity [167]. Tea polyphenols with a galloyl moiety were more active than those without a galloyl moiety and the number of galloyl groups was correlated with the anti-HIV-1 activity. Theaflavin 3,3'-digallate (57) inhibited HIV-1 replication, HIV-1-induced virus-cell fusion and cell-cell fusion, and gp41 six-helix bundle formation at low micromolar concentrations. Computeraided molecular docking studies indicated that theaflavin 3,3'- 


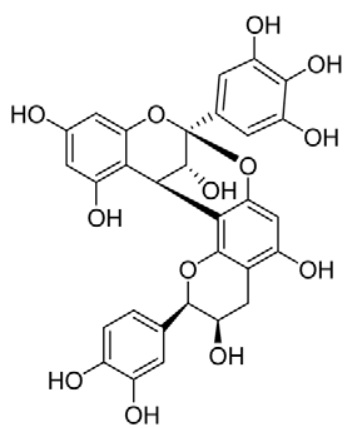

54<smiles>[R]C1Cc2c(O)cc(O)c3c2O[C@H](c2ccc(O)c(O)c2)[C@](O)(c2ccc(O)c(O)c2)Oc2cc(O)cc(O)c2[C@@H]31</smiles>

$\mathrm{R}=-\mathrm{OH}(55)$

$\mathrm{R}=\cdots \mathrm{OH}(56)$<smiles></smiles><smiles>O=C(OC1OC2OC3OC2C(O)C1OC(OC(=O)c1cc(O)c(O)c(O)c1-c1c(C(=O)O)cc(O)c(O)c1O)C3O)c1cc(O)c(O)c(O)c1</smiles>

$\mathrm{R}=$ galloyl $(57)$ 58

Fig. 7 Tannins.

digallate may fit in the hydrophobic pocket with its phenyl groups interacting with the hydrophobic residues in the pocket. Out of six hydrolysable tannins, two ellagitannins, corilagin (58) and repandusinic acid (59), inhibited HIV-1 protease ( IC $_{50}$ values $20.7 \mu \mathrm{M}$ and $12.5 \mu \mathrm{M}$, respectively), which indicates the importance of the hexahydroxydiphenoyl unit [67]. From a gallotannin-containing fraction of Phyllanthus amarus, the isolated ellagitannins geraniin and corilagin were shown to be the most active antiretroviral compounds [168]. These tannins blocked the interaction of HIV-1 gp120 with its primary cellular receptor CD4 and inhibited the enzymes integrase, reverse transcriptase and protease at low $\mu \mathrm{g} / \mathrm{mL}$ concentrations.

\section{Terpenes}

Some sesquiterpenes isolated from Litsea verticillata, collected in Vietnam, inhibited HIV-1 replication with $\mathrm{IC}_{50}$ values ranging from 38.1 to $91.0 \mu \mathrm{M}$, but the most active compound was a butenolide, 3epi-litsenolide $\mathrm{D}_{2}(\mathbf{6 0})$ with an $\mathrm{IC}_{50}$ of $9.9 \mu \mathrm{M}(\bullet$ Fig. 8) [169].

Several diterpenes from plants showed anti-HIV activity [170], [171], [172]. The diterpene 8,10,18-trihydroxy-2,6-dolabelladiene (61), a constituent of the Brazilian brown alga Dictyota

pfaffii, was found to inhibit HIV-1 reverse transcriptase, with an IC $_{50}$ value of $16.5 \mu \mathrm{M}$. It inhibited HIV-1 replication (IC $50.4 \mu \mathrm{M}$ ), and blocked HIV-1 infection in macrophages with $\mathrm{IC}_{50}$ values below $2 \mu \mathrm{M}$. It was suggested that this compound also blocked HIV-1 replication at a post-transcriptional step [173], [174]. HIV-1 reverse transcriptase-inhibiting diterpenes were also obtained from the alga Dictyota menstrualis [175].

Various triterpenes have been shown to exhibit anti-HIV activity. Two prostanes, garciosaterpenes A and C, inhibited HIV-1 reverse transcriptase, and were active in the syncytium assay with an $\mathrm{IC}_{50}$ of 5.8 and $37.0 \mu \mathrm{g} / \mathrm{mL}$, respectively, but with a low SI (3.4 and 1.9 , respectively) [176]. The limonoids limonin and nomilin were found to inhibit HIV-1 replication in several cell systems used, e.g., in PBMC isolated from healthy donors and infected with HIV-1 after incubation with limonin and nomilin; relatively large $\mathrm{IC}_{50}$ values of 60.0 and $52.2 \mu \mathrm{M}$ were obtained [177]. An unusual triterpene lactone, lancilactone $\mathrm{C}(\mathbf{6 2})$ from the stems and roots of Kadsura lancilimba inhibited HIV-1 replication $\left(\mathrm{IC}_{50}\right.$ $1.4 \mu \mathrm{g} / \mathrm{mL}$ ) with a SI of more than 71.4 [178]. A trinorcycloartane triterpenoid, lancifodilactone $\mathrm{H}$, and the A ring secocycloartane triterpenoids, lancifoic acid A and nigranoic acid, from Schisandra lancifolia, showed weak anti-HIV-1 activity, with $\mathrm{IC}_{50}$ values of $16.6,16.2$ and $10.3 \mu \mathrm{g} / \mathrm{mL}$, and $\mathrm{CC}_{50}$ values of $>200,104.9$ and $88 \mu \mathrm{g} / \mathrm{mL}$, respectively [179].

Anti-HIV triterpenes can be classified into five different categories according to their target and mechanism of action: entry inhibitors (by blocking virus adsorption of membrane fusion), reverse transcriptase inhibitors, protease inhibitors, virus maturation inhibitors, and products with an unknown mechanism of action [180]. Research on triterpenes has mainly focused on derivatives of oleanolic acid, betulinic acid and ursolic acid. The parent compound oleanolic acid inhibited HIV-1 replication in hu-<smiles>CCCCC=C1C(=O)OC(C)C1O</smiles>

60<smiles>C[C@H]1C=C[C@]2(C)CC[C@@H](C(C)(C)O)[C@H]2[C@@H](O)C[C@](C)(O)/C=C\C1</smiles>

61<smiles>CC1=CC[C@H]([C@H](C)C2CC[C@]3(C)C4=C(C=C(CCC(=O)O)C(=C(C)C)C=C4)CC[C@]23C)OC1=O</smiles>

62

63

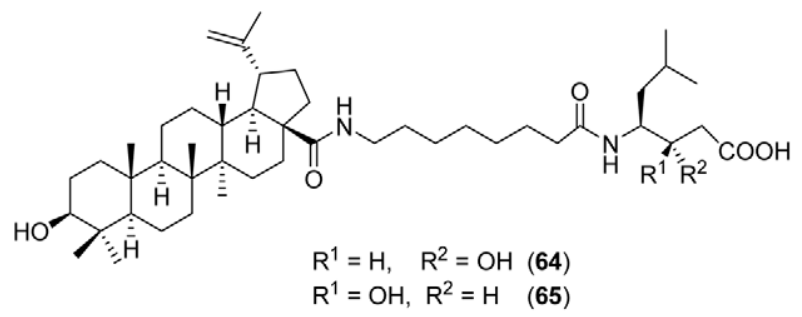

Fig. 8 Terpenes. 
man peripheral mononuclear cells ( IC $_{50}$ values: $22.7-24.6 \mu \mathrm{M}$ ) and monocyte/macrophages ( $\mathrm{IC}_{50}$ value: $57.4 \mu \mathrm{M}$ ) [181]. Oleanolic acid inhibited HIV-1 protease activity in vitro. Because of the structural resemblance of oleanolic and betulinic acid, and because derivatisation of the $\mathrm{OH}$ group in position 3 with an ester functionality strongly increased the anti-HIV activity of betulinic acid [182], semi-synthetic oleanolic acid derivatives with different ester groups at C-3 were prepared [183]. Oleanolic acid 3-0-3',3'-dimethyl succinate (63) was the most potent inhibitor of HIV, with an $\mathrm{IC}_{50}$ value of $0.5 \mathrm{ng} / \mathrm{mL}$, and a very high SI of 22400. In contrast, 3-0-(3',3'-dimethyl succinyl)-ursolic acid displayed only a weak anti-HIV activity ( IC $_{50} 2.1 \mu \mathrm{M}$, SI 23.6) [184]. 3-0-[3',3'-dimethyl succinyl]-betulinic acid was found to be a maturation inhibitor. It is responsible for disruption of the late-stage viral maturation processes of the Gag protein, resulting in a defective core structure around the viral RNA, and a non-infectious virus. This compound was the first member of a new class of anti-HIV drug candidates [185], [186]. Esterification of both the C-3 hydroxy and the C-28 carboxylic acid functionalities of betulinic acid resulted in even more potent compounds; e.g., the di-O-dimethyl succinyl derivative showed an $\mathrm{IC}_{50}$ value of $0.87 \mathrm{nM}$ and an SI of 42,400 [182], [187], [188]. In a structure-activity relationship study on betulinic acid derivatives, RPR103611 (64), a statin derivative, was found to be inactive against HIV-1 protease, reverse transcriptase, and integrase, but it acted as a fusion inhibitor [189], [190]. More recently, it was suggested that its antiviral activity was dependent on the stability of the gp120/gp41 complex [191]. Gp120 was proposed as the primary target for the anti-HIV activity of a stereoisomer of RPR103611, IC9564 (65) [192]. Both compounds appeared to be equally potent in their anti-HIV-1 and anti-fusion activities. However, the drug development process of RPR103611 was stopped due to its poor pharmacodynamic properties [193].

The combination of a 3,3-dimethyl succinyl side chain at C-3 and an aminoalkanoic side chain at $\mathrm{C}-28$ resulted in very active bifunctional anti-HIV compounds with $\mathrm{EC}_{50}$ values in the nanomolar range. They showed antifusion activity as well as maturation inhibition [194], [195].

\section{Conclusion}

This review clearly shows that the field of plant-derived compounds for chemotherapy of HIV is still booming. Many constituents have been isolated, identified and evaluated in vitro for anti-HIV activity, but in vivo studies are still scarce. It is only through carefully designed and conducted clinical trials with the purified active substance that the efficacy and safety of the compound can be unequivocally established. Therefore, it will be interesting to see if any of these putative anti-HIV compounds will ever reach the patient.

\section{Acknowledgements \\ $\nabla$}

Paul Cos is a postdoctoral researcher of the Fund for Scientific Research (FWO-Flanders).

\section{References}

1 Vlietinck AJ, De Bruyne T, Apers S, Pieters L. Plant-derived leading compounds for chemotherapy of human immunodefiency virus (HIV) infection. Planta Med 1998; 64: $97-109$
2 Matthee G, Wright AD, König G. HIV reverse transcriptase inhibitors of natural origin. Planta Med 1999; 65: 493-506

3 Cos P, Vanden Berghe D, De Bruyne T, Vlietinck AJ. Plant substances as antiviral agents: An update (1997-2001). Curr Org Chem 2003; 7: $1163-80$

4 Cos P, Maes L, Vanden Berghe D, Hermans N, Pieters L, Vlietinck A. Plant substances as anti-HIV agents selected according to their putative mechanism of action. J Nat Prod 2004; 67: 284-93

5 De Clercq E. The design of drugs for HIV and HCV. Nat Rev Drug Discov 2007; 6: $1001-18$

6 Pomerantz RJ, Horn DL. Twenty years of therapy for HIV-1 infection. Nat Med 2003; 9: 867-73

7 Flexner C. HIV drug development: the next 25 years. Nat Rev Drug Disov 2007; 6: 959-66

$8 \operatorname{Cos}$ P, Vlietinck AJ, Vanden Berghe D, Maes L. Anti-infective potential of natural products: how to develop a stronger in vitro proof-of-concept'. J Ethnopharmacol 2006; 106: 290-302

9 White EL, Chao WR, Ross LJ, Borhani DW, Hobbs PD, Upender V et al. Michellamine alkaloids inhibit protein kinase $\mathrm{C}$. Arch Biochem Biophys 1999; 365: 25 - 30

10 Hallock YF, Manfredi K, Dai J, Cardellina JH II, Gulakowski RJ, McMahon $J B$ et al. Michellamines D - F, new HIV-inhibitory dimeric naphthylisoquinoline alkaloids, and korupensamine E, a new antimalarial monomer, from Ancistrocladus korupensis. J Nat Prod 1997; 60: 677-83

11 Bringmann G, Holenz J, Weirich R, Rübenacker M, Funke C, Boyd MR et al. First synthesis of the antimalarial naphthylisoquinoline alkaloid dioncophylline C, and its unnatural anti-HIV dimer, jozimine C. Tetrahedron 1998; 54: 497-512

12 Bringmann G, Wenzel M, Ross Kelly T, Boyd MR, Gulakowski RJ, Kaminsky R. Octadehydromichellamine, a structural analog of the anti-HIV michellamines without centrochirality. Tetrahedron 1999; 55: $1731-40$

13 Karpas A, Fleet GWJ, Dwek RA, Petursson S, Namgoong SK, Ramsden NG et al. Aminosugar derivatives as potential anti-human immunodeficiency virus agents. Proc Natl Acad Sci USA 1988; 85: 9229-33

14 Watson AA, Fleet GWJ, Asano N, Molyneux RJ, Nash RJ. Polyhydroxylated alkaloids - natural occurrence and therapeutic applications. Phytochemistry 2001; 56: $265-95$

15 Taylor DL, Nash R, Fellows LE, Kang MS, Tyms AS. Naturally occurring pyrrolizidines: Inhibition of $\alpha$-glucosidase 1 and anti-HIV activity of one stereoisomer. Antiviral Chem Chemother 1992; 3: 273-7

16 Asano N, Nishida M, Kato A, Kizu H, Matsui K, Shimada Y et al. Homonojirimycin isomers and $\mathrm{N}$-alkylated homonojirimycins: structural and conformational basis of inhibition of glycosidases. J Med Chem 1998; 41: $2565-71$

17 Matsuno T, Orita K, Edashige K, Kobuchi H, Sato EF, Inouye B et al. Inhibition of active oxygen generation in guinea-pig neutrophils by biscoclaurine alkaloids. Biochem Pharmacol 1990; 39: 1255 -9

18 Kondo Y, Imai Y, Hojo H, Hashimoto Y, Nozoe S. Selective inhibition of Tcell dependent immune responses by bisbenzylisoquinoline alkaloids in vivo. Int J Immunopharmacol 1992; 14: 1181 -6

19 Furusawa S, Wu J. The effects of biscoclaurine alkaloid cepharantine on mammalian cells: implications for cancer, shock, and inflammatory diseases. Life Sci 2007; 80: 1073-9

20 Legrand-Poels S, Vaira D, Pincemail J, Van de Vorst A, Piette J. Activation of human immunodeficiency virus type 1 by oxidative stress. AIDS Res Hum Retroviruses 1990; 6: 1389-97

21 Okamoto M, Ono M, Baba M. Potent inhibition of HIV type 1 replication by an antiinflammatory alkaloid, cepharanthine, in chronically infected monocytic cells. AIDS Res Hum Retroviruses 1998; 14: 1239-45

22 Longanga Otshudi A, Apers S, Pieters L, Claeys M, Pannecouque C, De Clercq $E$ et al. Biologically active bisbenzylisoquinoline alkaloids from the root bark of Epinetrum villosum. J Ethopharmacol 2005; 102: 89 94

23 Duan H, Takaishi Y, Imakura Y, Jia Y, Li D, Cosentino M et al. Sesquiterpene alkaloids from Tripterygium hypoglaucum and Tripterygium wilfordii: A new class of potent anti-HIV agents. J Nat Prod 2000; 63: 357-61

24 Ishida J, Wang HK, Oyama M, Cosentino ML, Hu CQ Lee KH. Anti-AIDS agents. 46. Anti-HIV activity of harman, an anti-HIV principle from Symplocos setchuensis, and its derivatives. J Nat Prod 2001; 64: 958 60

25 Meragelman KM, McKee TC, Boyd MR. Siamenol, a new carbazole alkaloid from Murraya siamensis. J Nat Prod 2000; 63: 427-8 
26 Kongkathip B, Kongkathip N, Sunthitikawinsakul A, Napaswat C, Yoosook C. Anti-HIV-1 constituents from Clausena excavata: Part II. Carbazoles and a pyranocoumarin. Phytother Res 2005; 19: 728-31

27 Xu Z, Chang FR, Wang HK, Kashiwada Y, McPhail AT, Bastow KF et al. Anti-HIV agents 45 and antitumour agents 205. Two new sesquiterpenes, leitneridanins A and B, and the cytotoxic and anti-HIV principles from Leitneria floridana. J Nat Prod 2000; 63: 1712 -5

28 Hsieh PW, Chang FR, Lee KH, Hwang TL, Chang SM, Wu YC. A new antiHIV alkaloid, drymaritin, and a new C-glycoside flavonoid, diandroflavone, from Drymaria diandra. J Nat Prod 2004; 67: 1175-7

29 Silva EM, Cirne-Santos CC, Frugulhetti ICPP, Galvao-Castro B, Saraiva $E M B$, Kuehne ME et al. Anti-HIV activity of the Iboga alkaloid congener 18-methoxycoronaridine. Planta Med 2004; 70: 808 - 12

30 Leven M, Vanden Berghe DA, Vlietinck AJ. Plant antiviral agents IV. Influence of lycorine on growth pattern of three animal viruses. Planta Med 1983; 49: 109-14

31 Szlavik L, Gyuris A, Minarovits J, Forgo P, Molnar J, Hohmann J. Alkaloids from Leucojum vernum and antirettroviral activity of Amaryllidaceae alkaloids. Planta Med 2004; 70: 871 - 3

32 Wu PL, Lin FW, Wu TS, Kuoh CS, Lee KH, Lee SJ. Cytotoxic and anti-HIV principles from the rhizomes of Begonia nantoensis. Chem Pharm Bull 2004; $52: 345-9$

33 Mann DA, Frankel AD. Endocytosis and targeting of exogenous HIV-1 tat protein. EMBO J 1991; 10: $1733-9$

34 Rusnati M, Urbinati C, Caputo A, Possati L, Lortat-Jacob H, Giacca M et al. Pentosan sulfate as an inhibitor of extracellular HIV-1 tat. J Biol Chem 2001; 25: $22420-5$

35 Rusnati M, Coltrini D, Oreste P, Zoppetti G, Albini A, Noonan D et al. Interaction of HIV-1 tat protein with heparin. J Biol Chem 1997; 17: $11313-20$

36 Watson K, Gooderham NJ, Davies DS, Edwards RJ. Interaction of the transactivating protein HIV-1 tat with sulphated polysaccharides. Biochem Pharmacol 1999; 57: 775 - 83

37 Lüscher-Mattli M. Polyanions - a lost chance in the fight against HIV and other virus diseases? Antiviral Chem Chemother 2000; 11: 24959

38 Witvrouw M, De Clercq E. Sulfated polysaccharides extracted from sea algae as potential antiviral drugs. Gen Pharmacol 1997; 29: 497-511

39 Esté JA, Schols D, De Vreese K, Van Laethem K, Vandamme AM, Desmyter $J$ et al. Development of resistance of human immunodeficiency virus type 1 to dextran sulfate associated with the emergence of specific mutations in the envelope gp120 glycoprotein. Mol Pharmacol 1997; 52: $98-104$

40 Abrams DI, Kuno S, Wong R, Jeffords K, Nash M, Molaghan JB et al. Oral dextran sulfate (UA001) in the treatment of the acquired immunodeficiency syndrome (AIDS) and AIDS-related complex. Ann Intern Med 1989; $110: 183-8$

41 Flexner C, Barditch-Crovo PA, Kornhauser DM, Farzadegan H, Nerhood LJ, Chaisson RE et al. Pharmacokinetics, toxicity, and activity of intravenous dextran sulfate in human immunodeficiency virus infection. Antimicrob Agents Chemother 1991; 35: 2544-50

42 Hiebert LM, Wice SM, Jaques LB, Williams KE, Conly JM. Orally administered dextran sulfate is absorbed in HIV-positive individuals. J Lab Clin Med 1999; 133: 161 - 70

43 Shaunak S, Thornton M, John S, Teo I, Peers E, Mason P et al. Reduction of the viral load of HIV-1 after the intraperitoneal administration of dextrin 2-sulfate in patients with AIDS. AIDS 1998; 12: 399-409

44 De Clercq E. Current lead natural products for the chemotherapy of human immunodeficiency virus (HIV) infection. Med Res Rev 2000; 20: $323-49$

45 Hoshino T, Hayashi T, Hayashi K, Hamada J, Lee JB, Sankawa U. An antivirally active sulfated polysaccharide from Sargassum horneri (Turner) C. Agardh. Biol Pharm Bull 1998; 21: 730-4

46 Lee JB, Hayashi K, Hayashi T, Sankawa U, Maeda M. Antiviral activities against HSV-1, HCMV, and HIV-1 of rhamnan sulfate from Monostroma latissimum. Planta Med 1999; 65: 439-41.

47 Haslin C, Lahaye M, Pellegrini M, Chermann JC. In vitro anti-HIV activity of sulfated cell-wall polysaccharides from gametic, carposporic and tetrasporic stages of the Mediterranean red alga Asparagopsis armata. Planta Med 2001; 67: $301-5$

48 Rechter S, König T, Auerochs S, Thulke S, Walter H, Dörnenburh H et al. Antiviral activity of Arthrospira-derived spirulan-like substances. Antiviral Res 2006; 72: 197-206

49 Kashman Y, Gustafson KR, Fuller RW, Cardellina JH, McMahon JB, Currens MJ et al. The calanolides, a novel HIV-inhibitory class of cou- marin derivatives from the tropical rainforest tree, Calophyllum lanigerum. J Med Chem 1992; 35: 2735-43

50 Ishikawa T. Anti-HIV-1 active Calophyllum coumarins: distribution, chemistry and activity. Heterocycles 2000; 53: 453-74

51 Zembower DE, Liao S, Flavin MT, Xu ZQ Stup TL, Buckheit RW et al. Structural analogues of the calanolide anti-HIV agents. Modification of the trans-10,11-dimethyldihydropyran-12-ol ring (ring C)1. J Med Chem 1997; 40: 1005 - 17

52 Dharmaratne HRW, Tan GT, Marasinghe GPK, Pezzuto JM. Inhibition of HIV-1 reverse transcriptase and HIV-1 replication by Calophyllum coumarins and xanthones. Planta Med 2002; 68: 86-7

53 Yu D, Suzuki M, Xie L, Morris-Natschke SL, Lee KH. Recent progress in the development of coumarin derivatives as potent anti-HIV agents. Med Res Rev 2003; 23: 322-45

54 Dharmaratne HRW, Wanigasekera WMAP, Mata-Greenwood E, Pezzuto $J M$. Inhibition of human immunodeficiency virus type 1 reverse transcriptase activity by cordatolides isolated from Calophyllum cordatooblongum. Planta Med 1998; 64: 460-1

55 Quan Y, Motakis D, Buckheit R, Xu ZQ, Flavin MT, Parniak MA et al. Sensitivity and resistance to (+)-calanolide A of wild-type and mutated forms of HIV-1 reverse transcriptase. Antiviral Ther 1999; 4: 203 -9

56 Buckheit RW, White EL, Fliakis-Boltz V, Russell J, Stup TL, Kinjerski TL et al. Unique anti-human immunodeficiency virus activities of the nonnucleoside reverse transcriptase inhibitors calanolide $\mathrm{A}$, costatolide, and dihydrocostatolide. Antimicrob Agents Chemother 1999; 43: $1827-34$

57 Buckheit RW, Russell J, Xu ZQ Flavin M. Anti-HIV-1 activity of calanolides used in combination with other mechanistically diverse inhibitors of HOV-1 replication. Antiviral Chem Chemother 2000; 11: 321 7

$58 \mathrm{Xu}$ ZQ Hollingshead MG, Borgel S, Elder C, Khilevich A, Flavin MT. In vivo activity of $(+)$-calanolide $A$ in the hollow fiber mouse model. Bioorg Med Chem Lett 1999; 9: $133-8$

59 Xu ZQ Norris KJ, Weinberg DS, Kardatzke J, Wertz P, Frank P et al. Quantification of (+)-calanolide A, a novel and naturally occurring anti-HIV agent, by high-performance liquid chromatography in plasma from rat, dog and human. J Chromatogr B 2000; 742: 267 - 75

60 Newman RA, Chen W, Madden TL. Pharmaceutical properties of related calanolide compounds with activity against human immunodeficiency virus. J Pharm Sci 1998; 87: 1077-80

61 Sorbera LA, Castaner RM. Calanolide A. Drugs Fut 2001; 26: 285-6

62 Creagh T, Ruckle JL, Tolbert DT, Giltner J, Eiznhamer DA, Dutta B et al. Safety and pharmacokinetics of single doses of (+)-calanolide A, a novel, naturally occurring nonnucleoside reverse transcriptase inhibitor, in healthy, human immunodeficiency virus-negative human subjects. Antimicrob Agents Chemother 2001; 45: 1379-86

63 Kostova I, Raleva S, Genova P, Argirova R. Structure-activity relationships of synthetic coumarins as HIV-1 inhibitors. Bioorg Chem Appl 2006; 68274: 1 -9

64 Chen $Y$, Zhang $Q$, Zhang B, Xia P, Xia Y, Yang ZY et al. Anti-AIDS agents. Part 56: Synthesis and anti-HIV activity of 7-thia-di-O-(-)-camphanoyl-(+)-cis-khellolactone (7-thia-DCK) analogs. Bioorg Med Chem 2004; 12 : $6383-7$

65 Marquez N, Sancho R, Bedoya LM, Alcami J, Lopez-Perez JL, San Feliciano A et al. Mesuol, a natural occurring 4-phenylcoumarin, inhibits HIV-1 replication by targeting the NF-kB pathway. Antiviral Res 2005; 66: $137-45$

66 Kitamura K, Honda M, Yoshizaki H, Yamamoto S, Nakane H, Fukushima $M$ et al. Baicalin, an inhibitor of HIV-1 production in vitro. Antiviral Res 1998; 37: 131 - 40

$67 \mathrm{Xu} H X$, Wan M, Dong H, But PPH, Foo LY. Inhibitory activity of flavonoids and tannins against HIV-1 protease. Biol Pharm Bull 2000; 23: $1072-6$

68 Kim HJ, Woo ER, Shin CG, Park H. A new flavonol glycoside gallate ester from Acer okamotoanum and its inhibitory activity against human immunodeficiency virus-1 (HIV-1) integrase. J Nat Prod 1998; 61: 145-8

69 Critchfield JW, Coligan JE, Folks TM, Butera ST. Casein kinase II is a selective target of HIV-1 transcriptional inhibitors. Proc Natl Acad Sci USA 1997; 94: 6110-5

70 Haneda E, Furuya T, Asai S, Morikawa Y, Ohtsuki K. Biochemical characterization of casein kinase II as a protein kinase responsible for stimulation of HIV-1 protease in vitro. Biochem Biophys Res Commun 2000; 275: $434-9$

71 Harada S, Haneda E, Maekawa T, Morikawa Y, Funayama S, Nagata N et al. Casein kinase II (CK-II)-mediated stimulation of HIV-1 reverse 
transcriptase activity and characterization of selective inhibitors in vitro. Biol Pharm Bull 1999; 22: 1122-6

$72 \mathrm{Wu} J \mathrm{H}$, Wang $X \mathrm{H}$, Yi YH, Lee KH. Anti-AIDS agents 54 . A potent anti-HIV chalcone and flavonoids from genus Desmos. Bioorg Med Chem Lett 2003; $13: 1813-5$

73 Nakagawa-Goto K, Lee KH. Anti-AIDS agents 68. The first total synthesis of a unique potent anti-HIV chalcone from genus Desmos. Tetrahedron Lett 2006; 47: 8263-6

74 Cheenpracha S, Karalai C, Ponglimanont C, Subhadhirasakul S, Tewtrakul S. Anti-HIV-1 protease activity of compounds from Boesenbergia pandurata. Bioorg Med Chem 2006; 14: 1710-4

75 Mahmood N, Piacente S, Burke A, Khan A, Pizza C. Constituents of Cuscuta reflexa are anti-HIV agents. Antiviral Chem Chemother 1997; 8: 70-4

76 Yamaguchi K, Honda M, Ikigai H, Hara Y, Shimamura T. Inhibitory effects of (-)-epigallocatechin gallate on the life cycle of human immunodeficiency virus type 1 (HIV-1). Antiviral Res 2002; 53: 19-34

77 Williamson MP, McCormick TG, Nance CL, Shearer WT. Epigallocatechin gallate, the main polyphenol in green tea, binds to the T-cell receptor; CD4: potential for HIV-1 therapy. J Allergy Clin Immunol 2006; 118: $1369-74$

78 Rowley DC, Hansen MST, Rhodes D, Sotriffer CA, Ni H, McCammon JA et al. Thalassiolins A-C: new marine-derived inhibitors of HIV cDNA integrase. Bioorg Med Chem 2002; 10: 3619-25

79 Groweiss A, Cardellina JH, Boyd MR. HIV-inhibitory prenylated xanthones and flavones from Maclura tinctoria. J Nat Prod 2000; 63: $1537-9$

80 Cos P, De Bruyne T, Apers S, Vanden Berghe D, Pieters L, Vlietinck AJ. Phytoestrogens: recent developments. Planta Med 2003; 69: 589-99

81 Wang Q Ding ZH, Liu JK, Zheng YT. Xanthohumol, a novel anti-HIV-1 agent purified from hops Humulus lupulus. Antiviral Res 2004; 64: $189-94$

82 Lin YM, Anderson H, Flavin MT, Pai YHS, Mata-Greenwood E, Pengsuparp $T$ et al. In vitro anti-HIV activity of biflavonoids isolated from Rhus succedanea and Garcinia multiflora. J Nat Prod 1997; 60: $884-8$

83 Reutrakul V, Ningnuek N, Pohmakotr M, Yoosook C, Napaswad C, Kasisi $\mathrm{J}$ et al. Anti HIV-1 flavonoid glycosides from Ochna integerrima. Planta Med 2007; 73: 683-8

84 Alves CN, Pinheiro JC, Camargo AJ, de Souza AJ, Carvalho RB, da Silva $A B F$. A quantum chemical and statistical study of flavonoid compounds with anti-HIV activity. J Mol Struct (Theochem) 1999; 491: $123-31$

85 Mantas A, Deretey E, Ferretti FH, Estrada MR, Csizmadia IG. Structural analysis of flavonoids with anti-HIV activity. J Mol Struct (Theochem) 2000; 504: $171-9$

86 Alves CN, Pinheiro JC, Camargo AJ, Ferreira MMC, Romero RAF, da Silva $A B F$. A multiple linear regression and partial least squares study of flavonoid compounds with anti-HIV activity. J Mol Struct (Theochem) $2001 ; 541: 81-8$

87 Tao J, Qinxue H, Yang J, Li R, Li X, Lu C et al. In vitro anti-HIV and -HSV activity and safety of sodium rutin sulfate as a microbicide candidate. Antiviral Res 2007; 75: 227-33

88 He Y, Zeng S. Transport characteristics of rutin deca (H-)sulfonate sodium across Caco-2 cell monolayers. J Pharm Pharmacol 2005; 57: $1297-303$

89 Wang XJ, Jin YX, Ying JY, Zeng S, Tao TW. Determination of rutin deca $(\mathrm{H}-)$ sulfate sodium in rat plasma using ion-pairing liquid chromatography after ion-pairing solid-phase extraction. J Chromatogr B 2006; 833: $231-5$

90 Charlton JL. Antiviral activity of lignans. J Nat Prod 1998; 61: 1447-51

91 Valsaraj R, Pushpangadan P, Smitt UW, Adersen A, Christensen SB, Sittie $A$ et al. New anti-HIV-1, antimalarial, and antifungal compounds from Terminalia bellerica. J Med Chem 1997; 60: 739-42

92 Kuo YH, Li SY, Huang RL, Wu MD, Huang HC, Lee KH. Schizarin B, C, D and $\mathrm{E}$, four new lignans from Kadsura matsudai and their antihepatitis activities. J Nat Prod 2001; 64: 487 - 90

93 Hoang VD, Tan GT, Zhang HJ, Tamez PA, Van Hung N, Cuong NM et al. Natural anti-HIV agents - part 1: (+)-demethoxyepiexcelsin and verticillatol from Litsea verticillata. Phytochemistry 2002; 59: 325-9

94 Sun QZ, Chen DF, Ding PL, Ma CM, Kakuda H, Nakamura N et al. Three new lignans, longipedunins A-C from Kadsura longipedunculata and their inhibitory activity against HIV-1 protease. Chem Pharm Bull 2006; 54: $129-32$
95 Chen SW, Wang YH, Jin Y, Tian X, Zheng YT, Luo DQ et al. Synthesis and anti-HIV-1 activities of novel podophyllotoxin derivatives. Bioorg Med Chem Lett 2007; 17: 2091 -5

96 Zhu XK, Guan J, Xiao Z, Cosentino LM, Lee KH. Anti-AIDS agents. Part 61: anti-HIV activity of new podophyllotoxin derivatives. Bioorg Med Chem 2004; 12: 4267 - 73

97 Chen $M$, Kilgore N, Lee KH, Chen DF. Rubrisandrins A and B, lignans and related anti-HIV compounds from Schisandra rubriflora. J Nat Prod 2006; 69: 1697 - 701

98 Ovenden SPB, Wan SS, Sberna G, Tait RM, Rhodes D, Cox S et al. Globoidnan A: a lignan from Eucalyptus globoidea inhibits HIV integrase. Phytochemistry 2004; 65: 3255-9

99 Piccinelli AL, Mahmood N, Mora G, Poveda L, De Simone F, Rastrelli L. Anti-HIV activity of dibenzylbutyrolactone-type lignans from Phenax species endemic in Costa Rica. J Pharm Pharmacol 2005; 57: 1109-15

100 McDougall B, King PJ, Wu BW, Hostomsky Z, Reinecke MG, Robinson WE. Dicaffeoylquinic and dicaffeoyltartaric acids are selective inhibitors of human immunodeficiency virus type 1 integrase. Antimicrob Agents Chemother 1998; 42: 140-6

101 Zhu K, Cordeiro ML, Atienza J, Robinson WE, Chow SA. Irreversible inhibition of human immunodeficiency virus type 1 integrase by dicaffeoylquinic acids. J Virol 1999; 73: 3309-16

102 King PJ, Robinson WE. Resistance to the anti-human immunodeficiency virus type 1 compound l-chicoric acid results from a single mutation at amino acid 140 of integrase. J Virol 1998; 72: 8420 - 4

103 Pluymers W, Neamati N, Pannecouque C, Fikkert V, Marchand C, Burke TR et al. Viral entry as the primary target for the anti-HIV activity of chicoric acid and its tetra-acetyl esters. Mol Pharmacol 2000; 58: 641 -8

104 Sotriffer CA, Ni H, McCammon A. Active site binding modes of HIV-1 integrase inhibitors. J Med Chem 2000; 43: 4109-17

105 Lee DJ, Robinson WE. Preliminary mapping of a putative inhibitorbinding pocket for human immunodeficiency virus type 1 integrase inhibitors. Antimicrob Agents Chemother 2006; 50: 134-42

106 Lipinski CA, Lombardo F, Dominy BW, Feeney PJ. Experimental and computational approaches to estimate solubility and permeability in drug discovery and development settings. Adv Drug Delivery Rev 1997: 23: $3-25$

107 Veber DF, Johnson SR, Cheng HY, Smith BR, Ward KW, Kopple KD. Molecular properties that influence the oral bioavailability of drug candidates. J Med Chem 2002; 45: 2615-23

108 Kim SN, Lee JY, Kim HJ, Shin CG, Park H, Lee YS. Synthesis and HIV-1 integrase inhibitory activities of caffeoylglucosides. Bioorg Med Chem Lett 2000; 10: 1879-82

109 Mazumder A, Neamati N, Sunder S, Schulz J, Pertz H, Eich E et al. Curcumin analogs with altered potencies against HIV-1 integrase as probes for biochemical mechanisms of drug action. J Med Chem 1997; 40: 3057-63

110 Lin Z, Neamati N, Zhao H, Kiryu Y, Turpin JA, Aberham C et al. Chicoric acid analogues as HIV-1 integrase inhibitors. J Med Chem 1999; 42: $1401-14$

111 King PJ, Ma G, Miao W, Jia Q McDougall BR, Reinecke MG et al. Structure-activity relationships: analogues of the dicaffeoylquinic and dicaffeoyltartaric acids as potent inhibitors of human immunodeficiency virus type 1 integrase and replication. J Med Chem 1999; 42: $497-509$

112 Artico M, Di Santo R, Costi R, Novellino E, Greco G, Massa S et al. Geometrically and conformationally restrained cinnamoyl compounds as inhibitors of HIV-1 integrase: synthesis, biological evaluation and molecular modeling. J Med Chem 1998; 41: 3948-60

113 Charvat TT, Lee DJ, Robinson WE, Chamberlin AR. Design, synthesis, and biological evaluation of chicoric acid analogs as inhibitors of HIV-1 integrase. Bioorg Med Chem 2006; 14: 4552 - 67

114 Mazumder A, Raghava K, Weinstein J, Kohn KW, Pommier Y. Inhibition of human immunodeficiency virus type- 1 integrase by curcumin. Biochem Pharmacol 1995; 49: 1165 - 70

115 Taher MM, Lammering G, Hershey C, Valerie K. Curcumin inhibits ultraviolet light induced human immunodeficiency virus gene expression. Mol Cell Biochem 2003: 254: 289-97

116 Balasubramnyam K, Varier RA, Altaf M, Swaminathan V, Siddappa NB, Ranga $U$ et al. Curcumin, a novel p300/CREB-binding protein-specific inhibitor of acetyltransferase, represses the acetylation of histone/ nonhistone proteins and histone acetyltransferase-dependent chromatin transcription. J Biol Chem 2004; 279: 51163 -71

117 Appendino G, Ottino M, Marquez N, Bianchi F, Giana A, Ballero M et al. Arzanol, and anti-inflammatory and anti-HIV-1 phloroglucinol $\alpha$-py- 
rone from Helichrysum italicum spp. microphyllum. J Nat Prod 2007; 70: $608-12$

118 Kim HJ, Woo ER, Shin CG, Hwang DJ, Park H, Lee YS. HIV-1 integrase inhibitory phenylpropanoid glycosides from Clerodendron trichotomum. Arch Pharm Res 2001; 24: 286 - 91

119 Dat TN, Bae K, Wamiru A, McMahon JB, Le Grice SFJ, Bona M et al. A dimeric lactone from Ardisia japonica with inhibitory activity for HIV-1 and HIV-2 Ribonuclease H. J Nat Prod 2007; 70: 839-41

120 O'Keefe BR. Biologically active proteins from natural product extracts. J Nat Prod 2001; 64: 1373-81

121 Peumans WJ, Hao Q Van Damme EJM. Ribosome-inactivating proteins from plants: more than RNA N-glycosidases? Faseb J 2001; 15 : $1493-06$

122 Girbes T, Ferreras JM, Arias FJ, Stirpe F. Description, distribution, activity and phylogenetic relationship of ribosome-inactivating proteins in plants, fungi and bacteria. Mini Rev Med Chem 2004; 4: 461 - 76

123 Szalai K, Schöll I, Förster-Waldl E, Polito L, Bolognesi A, Untersmayr E et al. Occupational sensitization to ribosome-inactivating proteins in researchers. Clin Exp Allergy 2005; 35: 1354-60

124 Lee-Huang S, Huang PL, Bourinbaiar AS, Chen HC, Kung HF. Inhibition of the integrase of human immunodeficiency virus (HIV) type-1 by anti-HIV plant proteins MAP30 and GAP31. Proc Natl Acad Sci USA 1995; 92: $8818-22$

125 Sun Y, Huang PL, Li JJ, Huang YQ Zhang L, Huang PL et al. Anti-HIV agent MAP30 modulates the expression profile of viral and cellular genes for proliferation and apoptosis in AIDS-related lymphoma cells infected with Kaposi's sarcoma-associated virus. Biochem Biophys Res Commun 2001; 287: 983 -94

126 Wang YX, Neamati N, Jacob J, Palmer I, Stahl SJ, Kaufman JD et al. Solution structure of anti-HIV-1 and anti-tumor protein MAP30: structural insights into its multiple functions. Cell 1999; 99: 433-42

127 Nicolas E, Beggs JM, Haltiwanger BM, Taraschi TF. A new class of DNA glycosylase apurinic/apyrimidinic lyases that act on specific adenines in single-stranded DNA. J Biol Chem 1998; 273: 17216-20

128 Huang PL, Sun Y, Chen HC, Kung HF, Huang PL, Lee-Huang S. Proteolytic fragments of anti-HIV and anti-tumor proteins MAP30 and GAP31 are biologically active. Biochem Biophys Res Commun 1999; 262: $615-23$

129 McGrath MS, Hwang KM, Caldwell SE, Gaston I, Luk KC, Wu P et al. GLQ223 - an inhibitor of human immunodeficiency virus replication in acutely and chronically infected-cells of lymphocyte and mononuclear phagocyte lineage. Proc Natl Acad Sci USA 1989; 86: 2844 -8

130 Byers VS, Levin AS, Malvino A, Waites L, Robins RA, Baldwin RW. A phase-II study of effect of addition of trichosanthin to zidovudine in patients with HIV disease and failing antiretroviral agents. AIDS Res Hum Retroviruses 1994; 10: 413-20

131 Chan SH, Shaw PC, Mulot SFC, Xu LH, Chan WL, Tam SC et al. Engineering of a mini-trichosanthin that has lower antigenicity by deleting its C-terminal amino acid residues. Biochem Biophys Res Commun 2000; 270: $279-85$

132 Wang YY, Ouyang DY, Huang H, Chan H, Tam SC, Zheng YT. Enhanced apoptotic action of trichosanthin in HIV-1 infected cells. Biochem Biophys Res Commun 2005; 331: 1075-80

133 Au TK, Collins RA, Lam TL, Ng TB, Fong WP, Wan DCC. The plant ribosome inactivating proteins luffin and saporin are potent inhibitors of HIV-1 integrase. FEBS Lett 2000; 471: 169 - 72

134 Balzarini J. Inhibition of HIV entry by carbohydrate-binding proteins. Antiviral Res 2006; 71: 237 - 47

135 Balzarini J, Van Laethem K, Hatse S, Froeyen M, Peumans W, Van Damme $E$ et al. Carbohydrate-bindings agents cause deletions of highly conserved glycosylation sites in HIV gp120 - a new therapeutic concept to hit the Achilles heel of HIV. J Biol Chem 2005; 280: 41005-14

$136 \mathrm{Hu}$ Q, Mahmood N, Shattock RJ. High-mannose-specific deglycosylation of HIV-1 gp120 induced by resistance to cyanoverin-N and the impact on antibody neutralization. Virology 2007; 368: 145-54

137 Balzarini J. The $\alpha(1,2)$-mannosidase I inhibitor 1-deoxymannojirimycin potentiates the antiviral activity of carbohydrate-binding agents against wild-type and mutant HIV-1 strains containing glycan deletions in gp120. FEBS Lett 2007; 581: $2060-4$

138 Balzarini J, Van Laethem K, Peumans WJ, Van Damme EJM, Bolmstedt A, Gago F et al. Mutational pathways, resistance profile, and side effects of cyanoverin relative to human immunodeficiency virus type 1 strains with $\mathrm{N}$-glycan deletions in their gp120 envelopes. J Virol 2006; 80: $8411-21$
139 Botos I, Wlodawer A. Proteins that bind high-mannose sugars of the HIV envelope. Prog Biophys Mol Biol 2005; 88: 233 - 82

140 Saidi H, Nasreddine N, Jenabian MA, Lecerf M, Schols D, Krief D et al. Differential in vitro inhibitory activity against HIV-1 of alpha-(1 3 )- and alpha-(1-6)-d-mannose specific lectins: implication for microbicide development. J. Transl Med 2007; 5: 28-36

141 Balzarini J, Hatse S, Vermeire K, Princen $K$, Aquaro S, Perno CF et al. Mannose-specific plant lectins from the Amaryllidaceae family qualify as efficient microbicides for prevention of human immunodeficiency virus infection. Antimicrob Agents Chemother 2004; 48: $3858-70$

142 Balzarini J, Van Laethem K, Hatse S, Vermeire K, De Clercq E, Peumans $W$ et al. Profile of resistance of human immunodeficiency virus to mannose-specific plant lectins. J. Virol 2004; 78: 10617-27

143 Balzarini J, Neyts J, Schols D, Hosoya M, Van Damme E, Peumans W et al. The mannose-specific plant lectins from Cymbidium hybrid and Epipactis helleborine and the ( $\mathrm{N}$-acetylglucosamine)n-specific plant lectin from Urtica dioica are potent and selective inhibitors of human immunodeficiency virus and cytomegalovirus replication in vitro. Antiviral Res 1992; 18: 191 - 207

144 An J, Liu JZ, Wu CF, Li J, Dai L, Van Damme E et al. Anti-HIV I/II activity and molecular cloning of a novel mannose/sialic acid-binding lectin from rhizome of Polygonatum cyrtonema Hua. Acta Biochem Biophyi Sin 2006; 38: 70-8

145 Wang $\mathrm{HX}, \mathrm{Ng}$ TB. Examination of lectins, polysaccharopeptide, polysaccharide, alkaloid, coumarin and trypsin inhibitors for inhibitory activity against human immunodeficiency virus reverse transcriptase and glycohydrolases. Planta Med 2001; 67: 669- 72

146 Charan RD, Munro MHG, O'Keefe BR, Sowder RC, McKee TC, Currens M et al. Isolation and characterization of Myrianthus holstii lectin, a potent HIV-1 inhibitory protein from the plant Myrianthus holstii. J Nat Prod 2000; 63: 1170-4

147 Jiratchariyakul W, Wiwat $C$, Vongsakul $M$, Somanabandhu $A$ Leelamanit W, Fujii I et al. HIV inhibitor from Thai bitter gourd. Planta Med 2001; 67: 350-3

148 Wang $H, N g$ TB. Ginkbilobin, a novel antifungal protein from Ginkgo biloba seeds with sequence similarity to embryo-abundant protein. Biochem Biophys Res Commun 2000; 279: 407-11

149 Boyd MR, Gustafson KR, McMahon JB, Shoemaker RH, O'Keefe BR, Mori $T$ et al. Discovery of cyanovirin-N, a novel human immunodeficiency virus-inactivating protein that binds viral surface envelope glycoprotein gp120: potential applications to microbicide development. Antimicrob Agents Chemother 1997; 41: 1521 - 30

150 Asres K, Seyoum A, Veeresham C, Bucar F, Gibbons S. Naturally derived anti-HIV agents. Phytother Res 2005; 19: $557-81$

151 Tsai CC, Emau P, Jiang Y, Tian B, Morton WR, Gustafson KR et al. Cyanovirin-N gel as a topical microbicide prevents rectal transmission of SHIV89.6P in macaques. AIDS Res Hum Retroviruses 2003; 19: 535 41

152 Tsai CC, Emau P, Jiang Y, Agy MB, Shattock RJ, Schmidt A et al. Cyanovirin-N inhibits AIDS virus infections in vaginal transmission models. AIDS Res Hum Retroviruses 2004; 20: 11 -8

153 Giomarelli B, Provvedi R, Meacci F, Maggi T, Medaglini D, Pozzi G et al. The microbicide cyanovirin-N expressed on the surface of commensal bacterium Streptococcus gordonii captures HIV-1. AIDS 2002; 16: $1351-6$

154 Lagenauer LA, Berger EA. An anti-HIV microbicide comes alive. Proc Natl Acad Sci USA 2005; 102: 12294 - 5

155 Push O, Boden D, Hannify S, Lee F, Tucker LD, Boyd MR et al. Bioengineering lactic acid bacteria to secrete the HIV-1 virucide cyanovirin. J Acquir Immune Defic Syndr 2005; 40: 512-20

156 Bokesch HR, O'Keefe BR, McKee TC, Pannell LK, Patterson GM, Gardella $R S$ et al. A potent novel anti-HIV protein from the cultured cyanobacterium Scytonema varium. Biochemistry 2003; 42: 2578-84

157 Bewley CA, Cai M, Ray S, Ghirlando R, Yamaguchi M, Muramoto K. New carbohydrate specificity and HIV-1 fusion blocking activity of the cyanobacterial protein MVL: NMR, ITC and sedimentation equilibrium studies. J Mol Biol 2004; 339: 901 - 14

158 Mori T, O'Keefe BR, Sowder RC, Bringans S, Gardella R, Berg S et al. Isolation and characterization of griffithsin, a novel HIV-inactivating protein, from the red alga Griffithsia sp. J Biol Chem 2005; 280: $9345-53$

159 Reutrakul V, Chanakul W, Pohmakotr M, Jaipetch T, Yoosook C, Kasisit J et al. Anti-HIV-1 constituents from leaves and twigs of Cratoxylum arborescens. Planta Med 2006; 72: $1433-5$ 
160 Dharmaratne HRW, Tan GT, Marasinghe GPK, Pezzuto JM. Inhibition of HIV-1 reverse transcriptase and HIV-1 replication by Calophyllum coumarins and xanthones. Planta Med 2002; 68: 86-7

161 Reutrakul V, Anantachoke N, Pohmakotr M, Jaipetch T, Sophasan S, Yoosook $C$ et al. Cytotoxic and anti-HIV-1 caged xanthones from the resin and fruits of Garcinia hanburyi. Planta Med 2007; 73: 33-40

162 De Bruyne T, Pieters L, Deelstra H, Vlietinck A. Condensed vegetable tannins: biodiversity in structure and biological activities. Biochem Syst Ecol 1999; 27: 445 - 9

163 Khanbabaee K, van Ree T. Tannins: classification and definition. Nat Prod Rep 2001; 18: 641 -9

164 Amouroux P, Jean D, Lamaison JL. Antiviral activity in vitro of Cupressus sempervirens on two human retroviruses HIV and HTLV. Phytother Res 1998; 12: 367-8

165 Ma CM, Nakamura N, Hattori M, Kakuda H, Qiao JC, Yu HL. Inhibitory effects on HIV-1 protease of constituents from the wood of Xanthoceras sorbifolia. J Nat Prod 2000; 63: 238-42

166 De Bruyne T, Pieters L, Witvrouw M, De Clercq E, Vanden Berghe D, Vlietinck AJ. Biological evaluation of proanthocyanidin dimers and related polyphenols. J Nat Prod; 1999; 62: $954-8$

167 Liu S, Lu H, Zhao Q He Y, Niu J, Debnath AK et al. Theaflavin derivatives in black tea and catechin derivatives in green tea inhibit HIV-1 entry by targeting gp 41. Biochim Biophys Acta 2005; 1723: 270-81

168 Notka F, Meier G, Wagner R. Concerted inhibitory activities of Phyllanthus amarus on HIV replication in vitro and ex vivo. Antiviral Res 2004; 64: $93-102$

169 Zhang HJ, Huang NV, Cuong NM, Soejarto DD, Pezzuto JM, Fong HHS et al. Sesquiterpenes and butenolides, natural anti-HIV constituents from Litsea verticillata. Planta Med 2005; 71: $452-7$

170 Min BS, Hattori M, Lee KH, Kim YH. Inhibitory constituents against HIV-1 protease from Agastache rugosa. Arch Pharm Res 1999; 22: $75-7$

171 Rashid MA, Gustafson KR, Boyd MR. HIV-inhibitory cembrane derivatives from a Philippines collection of the soft coral Lobophytum species. J Nat Prod 2000; 63: 531 - 3

172 Alam MS, Quader MA, Rashid AA. HIV-inhibitory diterpenoid from Anisomeles indica. Fitoterapia 2000; 71: 574-6

173 Barbosa JP, Pereira RC, Abrantes JL, Dos Santos CCC, Rebello MA, Frugulhetti ICPP et al. In vitro antiviral diterpenes from the Brazil brown alga Dictyota pfaffii. Planta Med 2004; 70: 856-60

174 Cirne-Santos CC, Teixeira VL, Castello-Branco LR, Frugulheti ICPP, BouHabid DC. Inhibition of HIV-1 replication in human primary cells by a dolabellane diterpene isolated from the marine algae Dictyota pfaffii. Planta Med 2006; 72: 295 -9

175 Pereira HS, Leao-Ferreira LR, Moussatché N, Teieira VL, Cavalcanti DN, da Costa $\mathrm{LJ}$ et al. Effects of diterpenes isolated from the Brazilian marine alga Dictyota menstrualis on HIV-1 reverse transcriptase. Planta Med 2005; 71: 1019-24

176 Rukachaisirikul V, Pailee P, Hiranrat A, Tuchinda P, Yoosook C, Kasisit C et al. Anti-HIV-1 prostane triterpenes and digeranylbenzophenone from trunk bark and stems of Garcinia speciosa. Planta Med 2003; 69: $1141-6$

177 Battinelli L, Mengoni F, Lichtner M, Mazzanti G, Saija A, Mastroianni $C M$ et al. Effect of limonin and nomilin on HIV-1 replication on infected human mononuclear cells. Planta Med 2003; 69: 910-3
178 Chen DF, Zhang SX, Wang HK, Zhang SY, Sun QZ, Cosentino LM et al. Novel anti-HIV lancilactone $C$ and related triterpenes from Kadsura lancilimba. J Nat Prod 1999; 62: $94-7$

179 Xiao WL, Tian RR, Pu JX, Li X, Wu L, Lu Y et al. Triterpenoids from Schisandra lancifolia with anti-HIV-1 activity. J Nat Prod 2006; 69: 277-9

180 Huang L, Chen $\mathrm{CH}$. Molecular targets of anti-HIV-1 triterpenes. Curr Drug Target Infect Disord 2002; 2: 33-6

181 Mengoni F, Lichtner M, Battinelli L, Marzi M, Mastroianni CM, Vullo V et al. In vitro anti-HIV activity of oleanolic acid on infected human mononuclear cells. Planta Med 2002; 68: $111-4$

182 Sun IC, Shen JK, Wang HK, Cosentino LM, Lee KH. Anti-AIDS agents. 32. Synthesis and anti-HIV activity of betulin derivatives. Bioorg Med Chem Lett 1998; 8: 1267-72

183 Kashiwada Y, Wang HK, Nagao T, Kitanaka S, Yasuda I, Fujioka T. AntiAIDS agents. 30. Anti-HIV activity of oleanolic acid, pomolic acid, and structurally related triterpenoids. J Nat Prod 1998; 61: 1090 - 5

184 Kashiwada Y, Nagao T, Hashimoto A, Ikeshiro Y, Okabe H, Cosentino LM et al. Anti-AIDS agents 38 . Anti-HIV activity of 2-O-acylursolic acid derivatives. J Nat Prod 2000; 63: 1619-22

185 Zhou J, Yuan X, Dismuke D, Forshey BM, Lundquist C, Lee KH et al. Small-molecule inhibition of human immunodeficiency virus type 1 replication by specific targeting of the final step of virion maturation. J Virol 2004; 78: 922 -9

186 Lee $\mathrm{KH}$. Current developments in the discovery and design of new drug candidates from plant natural product leads. J Nat Prod 2004; 67: $273-83$

187 Kashiwada Y, Chiyo J, Ikeshiro Y, Nagao T, Okabe H, Cosentino LM et al 3,28-Di-O-(dimethylsuccinyl)-betulin isomers as anti-HIV agents. Bioorg Med Chem Lett 2001; 11: $183-5$

188 Sami A, Taru M, Salme K, Jari YK. Pharmacological properties of the ubiquitous natural product betulin. Eur J Pharm Sci 2006; 29: 1 - 13

189 Soler F, Poujade C, Evers M, Carry JC, Hénin Y, Bousseau A et al. Betulinic acid derivatives: A new class of specific inhibitors of human immunodeficiency virus type 1 entry. J Med Chem 1996; 39: 1069-83

190 Evers M, Poujade C, Soler F, Ribeill Y, James C, Lelièvre Y et al. Betulinic acid derivatives: A new class of human immunodeficiency virus type 1 specific inhibitors with a new mode of action. J Med Chem 1996 39: $1056-68$

191 Labrosse B, Treboute C, Alizon M. Sensitivity to a nonpeptidic compound (RPR103611) blocking human immunodeficiency virus type 1 Env-mediated fusion depends on sequence and accessibility of the gp41 loop region. J Virol 2000; 74: 2142 - 50

192 Holz-Smith SL, Sun IC, Jin L, Matthews TJ, Lee KH, Chen CH. Role of human immunodeficiency virus (HIV) type 1 envelope in the anti-HIV activity of the betulinic acid derivative IC9564. Antimicrob Agents Chemother 2001; 45: 60-6

193 Huang L, Zhang L, Chen CH. Potential drug targets on the HIV-1 envelope glycoproteins, gp120 and gp41. Curr Pharm Design 2003; 9: $1453-62$

194 Huang L, Yuan X, Aiken C, Chen CH. Bifunctional anti-human immunodeficiency virus type 1 small molecules with two novel mechanisms of action. Antimicrob Agents Chemother 2004; 48: 663-5

195 Aiken C, Chen $\mathrm{CH}$. Betulinic acid derivatives as HIV-1 antivirals. Trends Molecular Med 2005; 11: $31-6$ 